綜

\title{
動物性蛋白體, 血清學的特異性
}

\section{問題二就テ}

\section{第 1 編 動物性蛋白體, 特異性研究概觀（其 1)}

京都帝國大學醫學部微生物學教室（主任 木村教授）

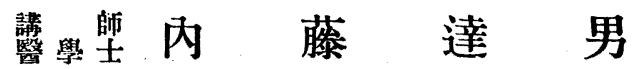

目

序言

第 1 編 動物性蛋白體/特黑性研究㮽觀

粕 言

第 1 章 吾教室二於々ル特異性問題/業績

第 1 節 奥田氏 「哺乳動物ノ血清學的特殊 性」二就了

第 2 節 赤松氏 /「蛋白免疫反㢈 /特黑性=

關スル賽驗的研究」二就

第 3 節 吾教室ニ於タル種屬特異鉴二關スル 業績

第 4 節 吾教室二於ヶル藏器特異性二關スル 業綪

第 5 節 本章/總括

第 2 章 種族特異性問題/概况

\section{次}

第 1 節 種屬特異性問题二就イテノ回頼

第 2 節 類屬反礁二就イテ

第 1 項 免疫操作卜類屬反應

第 2 項 免疫血清, 特異化法

第 3 項 檢查方法上二於ヶル考按

第 3 節 異型反應二就

第 1 項 非特異性反隹

第 2 項 異性反應

第 4 節 種屬特異性 ノ生物學的業績

第 1 項 人猿 ᄀ鑑别

第 2 項 同種血球凝集素

第 3 項 哺乳類以下/鑑別

第 5 節 本章/總括的考察

序

言

過去 1 ケ年二亘ッラ渡邊助教授指導ノ下二檢索そラレタ「臟器特異性」二關 スル研究ガ, 大過ナクソノ報告ヨ一縓トシラ本誌前號ニ公ニスルコトガ出來タ ノハ此上ナク喜バシイコトデアル，然レドモ，氏ガ「今回ノ研究?吾等二八全 ク新奇二企劃セラレ僅カニ 1 ケ年ニテ何等カ成果ヨアグヤウト焦慮シタタタ, 却亏所期八目的二達セズ極メラ不滿足ナ成績ヨり公表スルコトガ出來ナカッタ

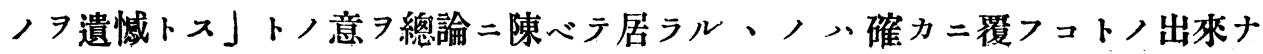


イ事實デアッラ，殊二吾等共同研究者ガ其責任ノ太半ヨ負ハネバナラヌコトハ 勿論デ，共二遺喊ニ堪へナイノデアル．而シテ其成果ノ如何ハ別トシテ，今回 ノ企八,ソノ規模卜抱負二於テ遠大ナモノガアリ，且ツ其用意ト考察二特二周到 ヨ期シタ點二於テ，吾等ノ恩師デアル畏敬スベキ清野教授が當教室ニ於イテ成 シ逐グラレタ昫爛タル業績, 掉尾习飾ルモノト自負シラ何等耻ズル所ナク，又 新進木村教授ニョッラ新興ノ意氣橫㵝タル當教室入入置土産トシテ上乘デアル ト推賞シテモ亦憚ラナイト信ズルノデアル，硃二，渡邊助教授ガ未が所期ノ成

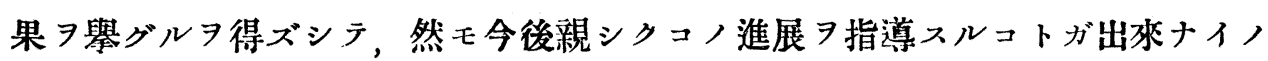
ヨ不本意卜七ラレテ, 特二吾等二期待 $尹$ 殘シラ渡歐セラレタ心事二想到スル時,

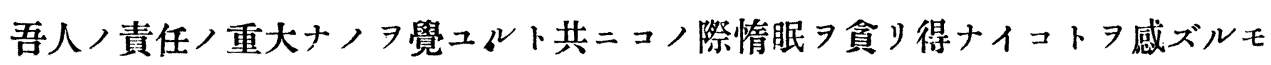
ノデアル.

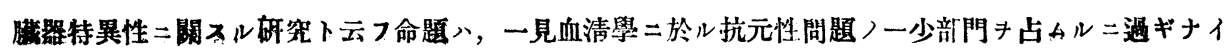

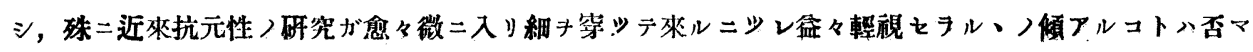

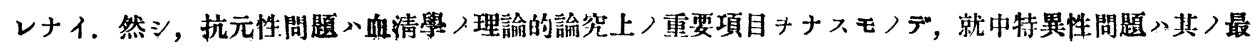

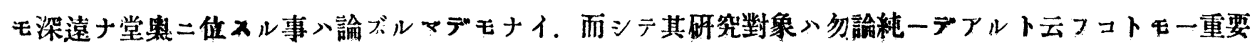

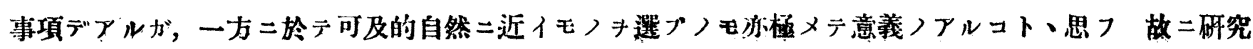

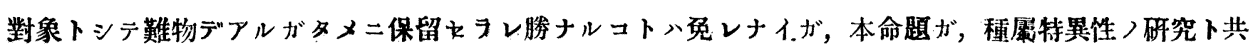

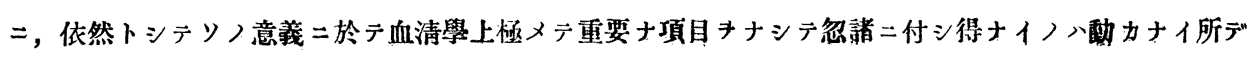

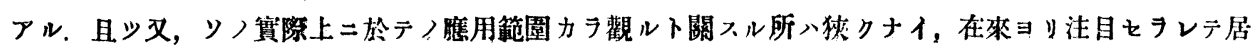

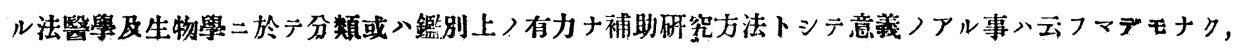

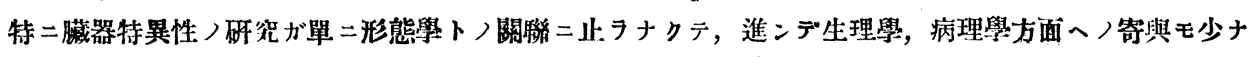

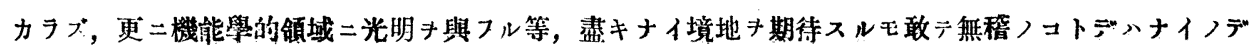

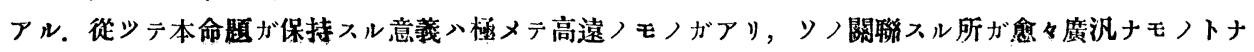

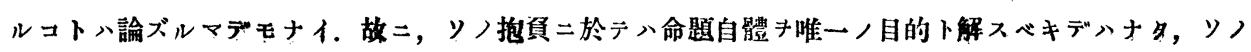

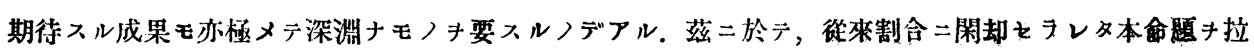

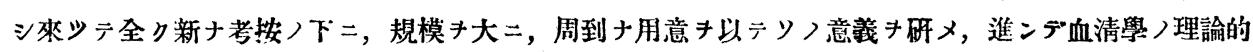

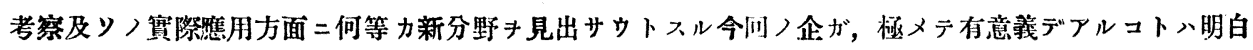

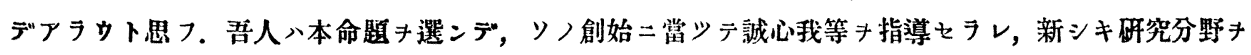

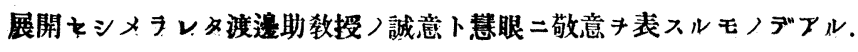

余入，今度幸ニモコノ有意義ナル檢索ノ樞機二垒與スルヨ得テ最モ親シク渡 邊助教授二師事シター人トシテ, 特二全氏/事 $习$ 良ク理解シ, 刃ソノ今後二 期待七ラレル所 $习$ 適確二威受シ得ルモノト自負スルト共二, 敢テメ/責任/重 大ナルタ感ズルモノデアル．且ッ，余一個トシテハ，血清學二入門ノ頭初カラ 抗元性問題，殊二特異性二關シテ警異ト共二興味 抱キ，更二今日二於テハ微 


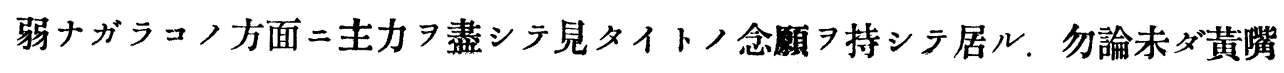
ノ身习以テ綜說的叙述习試ミルノ八鳥滸ノ沙汰デアルガ，幸二過去 1 ケ年二於 テ共同研究者卜相共二研鑚收集シタ文獻ガ少クナイノデ, コノ際此レヨ整理シ テ余等同人，備忘䤵トデモ云フベキモノヨ作ッテ置クダケデモ有意義ダト思、 ルルノデ,僣上ナガラ敢テカ、ル企ヨ目論ムダノデアル，而シテ，渡邊氏ガ渡歐

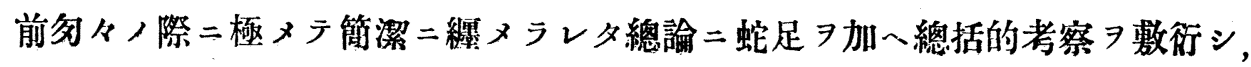
進ンデ余ガ現在保持シテ居ル特異性研究二關スル所懷习附記シテ, 諸賢ノ御教 示 ヨ仰ギ今後二資セムト志シタ次第デアル。

然ルニ他方二於テ, 吾等入最近, 新二先進努力ノ䊅晶ブフル Kolle, Kraus, u. Uhlenhuth $>$ Handbuch

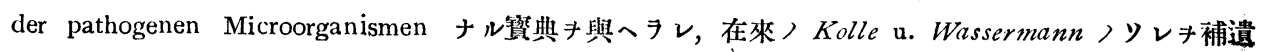
スルキ得テ，綜括的考察ナナス二最モ恰適ノ時機二際會シダノデアル。顧ルニ，本那二於テハ當教室， 㓣始者松下博士ハ, 主トシシ Kolle u. Wassermann 二據テ, 彼ノ大作寄生虫性病論ナル然二ノ賽典

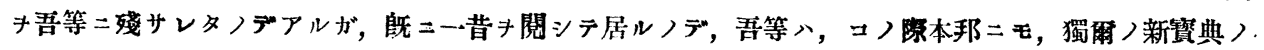

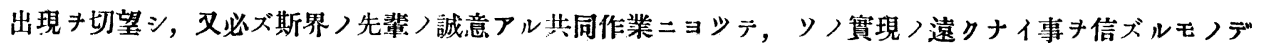
アル. 余ハソノ希求ノ切ナルモノガアルダケニ, 已キ顧ズ此ノ些タタル微著キ發表スルニ際シテ敢テ附 訅シテ置キタイノデアル。

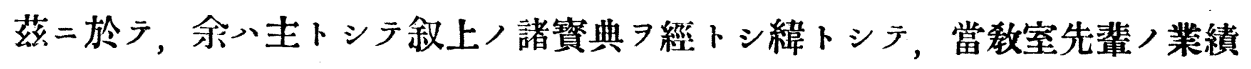
及今回ノ宿題, 研究考察等 羅針盤卜シテ,「動物性蛋白體ノ特異性問題」ナル 大海二研究ノ忛 7 進メャウト思フ。幸二余ガ微衷 7 諒トシラ御教示二客ナラ ズ，今後二期スルノ微意 藏器及種族特異性 主眼トシテ抗元特異性問題 7 考察スルコトトナシ, (1) 當

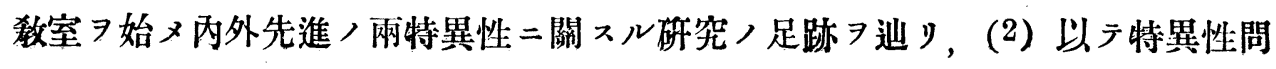
題八諸命題ノ意義 $ᄏ$ 明カニシ, 又ソノ研究方法 7 論究シ, (3) 最後ニソノ成果 ヨ精查シ, 今後二向ッテノ期待 陳ブルノ順序

序ヨ結ブニアタッテ，カ、ル僣上ナ企ヨ認容セラレタル清野教授及ビ漞シク 御棱閱・御教示二其勞 $\ni$ 惜マレナイ木村教授二對シテ梁謝ノ意 $习$ 表ス. 


\section{第 1 編 動物性蛋白體ノ特異性問題概稫}

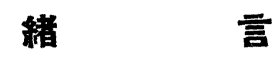

本編ハソノ表題ノ示スャウニ特異性問題全般二亘ルモノデハナイ, 序言ニモ 述べタャウ二, 藏器及種屬特異性, 郎チ生物學卜關聯スル抗元特異性問題ノミ二 就イテンノ先進ノ業績 異性問題, 意義, 及ビンノ關聯スべキ領域等 7 明確ニシテ置クコトガ順序カモ 知レナイガ，然シソノ歴史的推移カラ觀ルモ，又解說/都合カラスルモ，コレ

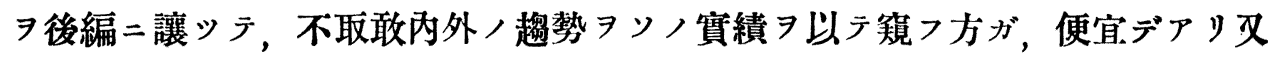
容易デアルト思フ。故ニ余ハ, 先ッ゙當教室ノ業績 7 紹介シ，續イテ內外先進， 跡习挆ッテ，實際方面カラ本命題 會得シャウトスルモノデアル。

\section{第 1 章 當数室ニ於ケル特異性問題二 閵スル業瞔}

清野敎授ガ吾ガ微生物學教室二擔任セラレタノ八大正 9 年デアシテ，爾爽略 七星霜 $\ni$ 閲シ, ソノ間幾多ノ俊髭 呈シタコトハ周知ノョトデアル。殊ニ,ソノ研究領域ガ廣ク, 方針ガ多樣デ, 且 ッ其ノ着眼ノ慧偉デアルノト，抱負ガ遠大デ含蓄ノ深淵デアッタコトハ比類ナ シト吾等ガ誇示スルモ敢テ過言デハナイト信ズルモノデアル．而シテ，コノ間 二在ッテ渡邊助教授ガ, 抗元特異性問題, 殊二種屬並二藏器二就テノ研究八就 中重要ナ役割 ヨ演ジタモノトシテ推擧シタノ八, 克ク恩師ノ意䘚タ理解セラレ タモノトシテ敬服スル所デアル，佅二，全氏ガ䢃頭紹介セラレタ奥田氏等ノ業 績八，ソノ前後 スルハ刎論，又之レヨ內外二誇示シテ耻シクナイノデアル．故二，考按ト解說 ノ容易十點カラ, 蛇足ナガランノ概要 紹介シテ富教室ノ赹勢 惟シタノデアル。

\section{第 1 節 奧田氏ノ「哺闺動物ノ血清學的 特殊性」三就テ}

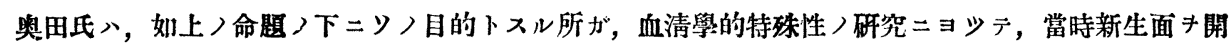

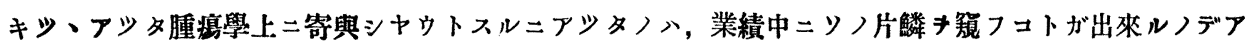

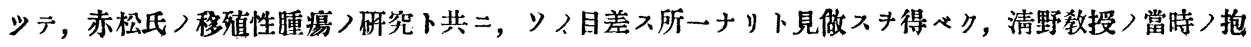


内藤達男述

(2515)

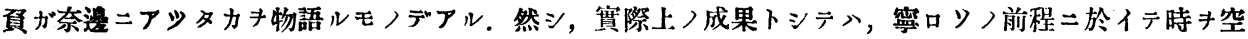

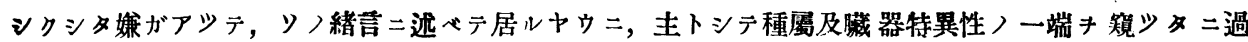
ギナイ、ソノ原著ハ, 前後 5 回ニ及ンデ關スル所ハ多岐デアルが, 大略特異性論究上ノ研究方法論卜モ

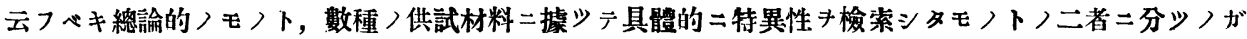
便宜デアル。

1. 血清學發達〉歷史八向新シク，特ニリノ方法論的考察二末ダ不備ノ點がアリ，ソレが第吾等八研究

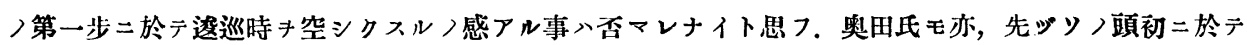
研究方法二就テ可ナリ綿密ナ吟味才試ミテ居ル。

第 I 編ハ沈降反應ノ特異性及銳敏度二就テデアル．先ヅ血清抗元 者沸，凝固及ビ生ノマ、ノ3先没元ノ特異性制定上八優劣 7 比較シ，前 2 者八特 異性ノ點カラ云フト類族反應ガ强ク生蛋白ニ劣ルノデアル。コレニ就イテハ, 造抗元性二比シテ毒性ガ强ク一般二泩射回數 ジ,引續イテ實驗的二,泩入回數ガ特異性二關係 性刃强》，從ッテ先疫元ハソノ造抗元性ノ强弱ニヨッテモ間接二特異性ノ强弱 ヨ゙左右シ，特異性高キ抗血清 $\exists$ 得ルニハ泩入回數ノ少ナイ方ガョイトノ結果 得タノデアル。

次ギ二, 動物分類學上近緣デアルまうす對らって二於テ, 家鬼 7 免疫獸トナシ ・タル從來，實驗二於テ特異性ガ可ナリ强度二現ハレ，動物學上ノ分類ト埾少， 一致 7 缺グ事實 7 Uhlenhuth ガ指摘シテョリ, 本特異性問題ガ未ダ歸一七ラレテ 居ラナイノデ, コレガ追試 行ヒ, 疎緣ナ家雞 7 免疫動物二選ビ, 類屬反應 7 明 カナラシメラ親近度ノ大ナルタ立證シタ。コ，事實カラ著者、特異性ノ制定二 當ッテハ交叉允疫法、論ズルマデモナク，一般二造抗元二近緣ナル先疫動物 選ブ時ニ於テ特異性ガ著明ニ現レ，踈緣ナモノ八類族反應ガ强ク出現スルモノ ニアラズャ，從ッテ先疫獸ノ選擇モ亦特異性血清ノ獲得二當り一定ノ關係 スベキモノデハナカラウカトノ考按ヨ抱イタノデアル. 則チ第 3 回報告，第 5 編、動物種ノ選擇卜免疫血清ノ特異性卜ノ關係 7 實驗的二檢甞シタモノデ，免 疫元トシテハ哺乳動物ノ諸種血清蛋白(山羊生血清, 者沸牛血清, 者沸凝固牛血

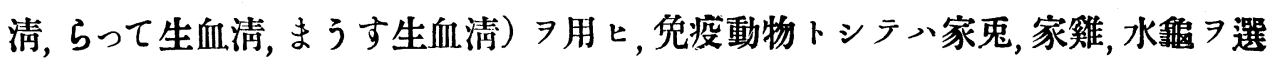
ビ，免疫血清ノ特異性入（1）先疫元タル動物卜先没動物トノ血緑距離二相反 シテ增减シ，(2) 免疫動物ノ動物學上ノ進化ノ程度二略相併行シテ墦加ストノ

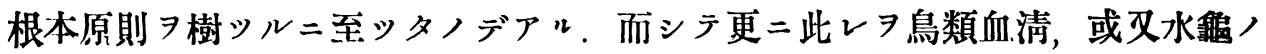
血清ヨ免疫元トシテ共ニ叙上ノ原理ヨ確證スルコトガ出來タノデアル.

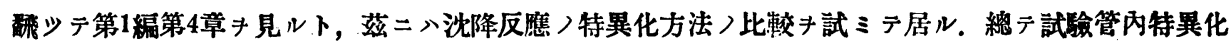


法二就テデアリテ，Weichardt ノ能和吸收法二於テハ，ソノ吸收元ノ量キ加减シテ系統的二觀察シ，

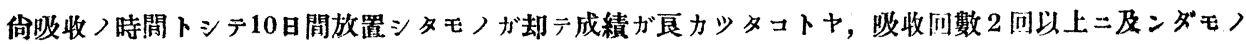

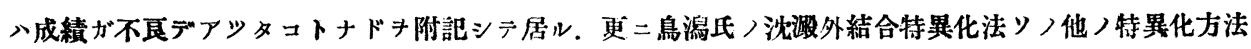
キモ比較シテ居ルガ特二注目スベキモノハナイ、第 2 編ハ補體結合反雇ノ特異性及其ノ鏡敏度二就テ, らって對まうす及山羊對牛ノ特異性ハ著明二銳敏度王高度二現ハレテ居ル。更二祼體結合反應ノ方法論

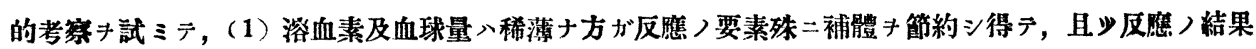
ノ制定二便利ア゙アル，(2) 補體ノ使用量ハ補體價自體が最好適デアルが，過剩ノ時八銳敏度が最マリ 特異性制定二モ過誤か割合二少ナイノデ在來〉1倍牛，乃至 2 倍量入適當デアル，(3) 特殊血清モ僅少） 過量ハ關係がナイカラ控目二用フル要ハナイ（4）補體結合反應ハリノ反應時間二依当特異性ノ現レ 方が違フカラ, ソノ伸縮ニョッテ特異性キ加减スル事が出來ル，例之特黑性キ顯著ナラシムルニハ反礁

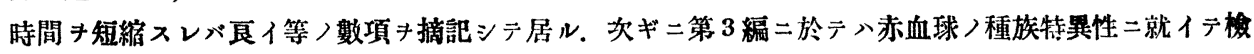

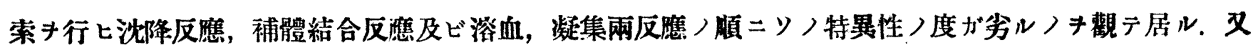

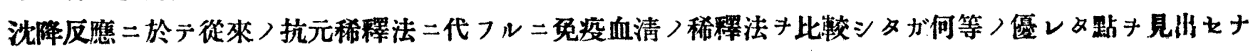
カッタ.ソノ他反應元トシテノ抗元八個性的美異キ見出サナイ, 唯りノ新蕉或八防腐劑ノ有無等八可ナ リ影㗽キ與フルモノデアルトシテ居ル。 又種屬特異性ノ制別二當ッテ鳥潟教授二從七沈澌計キ用七テ居

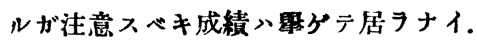

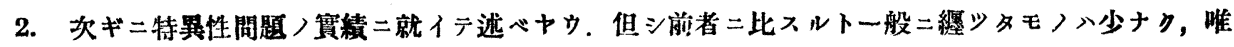
コノ方面ノ重要ナ各項二開拓ノ標識キ樹デトデモ譬フベキデアル，然シ之ニョッテ望等二當領域ノ概 况キ紹介シ且指針キ與へタ事入極メテ大デアル。

先ヅ第 1 篇中二八山羊・牛及ビらって・まうす間ノ特異性 7 追試シ, 更二赤血球 习抗元トセル種屬特異性研究、，第2回報告第3編二於イテ，血清

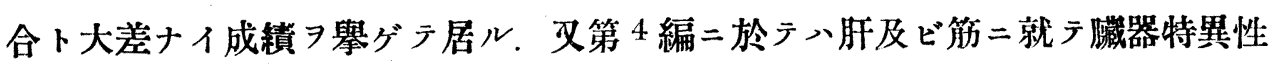
ト併七テ觀察シ共二兩特異性ノ存在 吸收スルト臟器特異性ノミ殘留スル。更二第 4 回報告第 6 編二於テン, 諸觔蛋 白ノ臟器特異性二就テ，橫紋筋，心筋，平滑筋八微弱乍ラソノ順序二近親關係 ヨ示シ, 且ッ反應, 銳敏度モ亦ソノ順序ニ從フコトヨ沈降, 䋠體結合雨反應

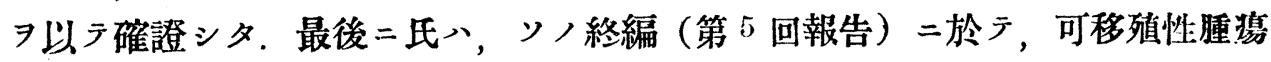
ノ特異性ノ推移 7 血清學的二觀察シテ居ル.ソノ成績 $コ$ 摘錄スルト, 卯化鳥卵 內二發育スル移殖組織入正常胎生組織二於イテハ原始, 種屬特異性 $习$ 保特スル

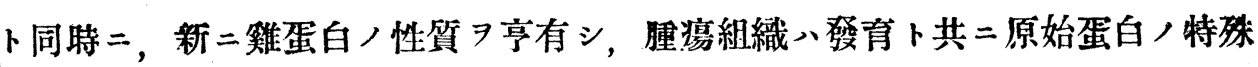
性 失フニ至ルノデアル，又鸣腦內二於イテらって癌，らって肉腫，まうす癌腫 八移殖二成功シ，之二於テモ宿主ノ特異性 7 亨有スルト共二, 一方原始ノ特貿

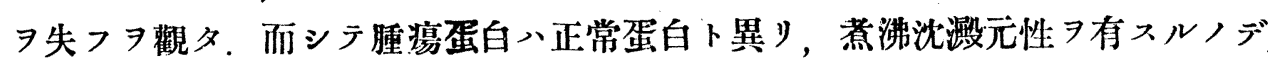
一種ノ咸器特異性 7 現スモノト見做シ得ト云ッラ居ル。

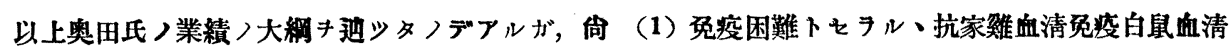

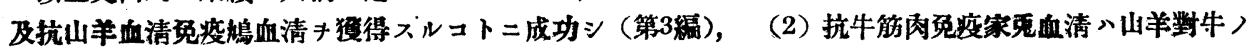


血液鑑別二當ツテ抗牛血清免疫血清ヨリモ有利ナコトキ指摘シテ居ル2 點キ附記シテ，本節キ終ル事ト スル.

\section{第 2 節 赤松氏ノ「蛋白兔度反應ノ特異 性ニ關スル實驗的研究」三就テ}

赤松氏ハ奥田氏下期キ同シフシ，相前後シテ共二特異性研究上出色ノ業績き琖サレタノデアル。本命

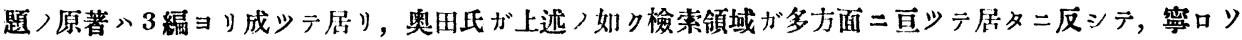
ノ取材ノ數ハ少ナイノデアルが，ソノ3 編ハ共二各獨雨ノ方面斗探り得テ，而モ總テ完結サレタモノデ アル.

1. 就中「特二血清沈降反應二於ケル反憵元ノ稀釋法二就テ」八今问ノ宿題二於イテ抗元ノ量的單位 ノ考察キ特二重要視シタ主因キナシ，有力ナ參考トナッタモノデプ。

從來，血清抗元ノ特異性ノ論究二當ッテ,反應元タル血清八,單二探取原血清 ヨ標準トシテ稀釋シタノデアルガ，コノ㙫合ニ於イテモ他ノ單一蛋白體/如ク 蛋白含有量二留意スルノ要ハナイカ，郎チ一般二反應元、蛋白絕對量 一スべキカ，或八當該動物ノ原血清卜同一蛋白量トナス心゙キモノカ，ソノ何レ 二據ルべカノ礙問二逢着シタ。茲二於テ氏ハ血清及血色素, 雨抗元ニテ種屬 特異性ノ制定上ニ於ヶル兩標隼ノ優劣 7 比較シ，血清ト血色素トノ敦レ ズ, 含有蛋白量ソノモノヨ整一ニスルノガ合理的デアルトノ結諭ニ達シタノデ アル．此レニ依ルト血清學上ノ反應元、，ソノ如何ナル鹪合 於テハ含有蛋白ノ絕對量 スコトガ出爽ルト考へテョイ，氏ハ亦大澤，伊澤氏等ト各種動物血清ノ蛋白量 及ビ二三ノ物理化學的性狀ノ異同 ヨ觀察シ, 可ナリ差異ガアルモノデ, 血清反應 ニ於イラ叙上ノ點ガ極メテ重要デアルべキ一證左ヨ加ータノデアル．引續イテ 叙上ノ新考按二立脚シテ，血清及血色素 $尹$ 抗元トシテ鳥類間ノ近親關係 シテ居ルガ都合上次節二於イテ述べャウ.

2. 最後二，娔疫經過中二於ヶル主副沈降素，消長並二其／相互關係卜云 命題ノ下二, 免疫經過二伴フ血清沈降素ノ消長 $\ni$ 追ウテ，陰性，上昇，稽留，下降

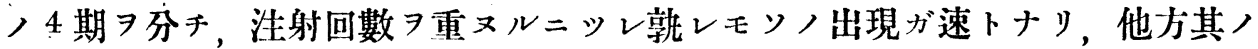
期間ガ短縮セラレ,主㢦ノ差ハ接近スルノヨ確メタ。是等ノ諸點カラ観テ, 血清 沈降素ハ1 回泩射後13日目ノモノガ比較的良好デアルト云ッテ居ル. 泩射回數 ト主副ノ關係、第 1 節ニ於テモ記述シテ居ル所デ，又山林氏ガ血球 
(2518)

凝集，雨抗體ノ主副ノ產出狀態ガ亦全樣デアルコトア確メタノト悉ク符節 シテ，宿題ノ考察二於テ吾人ノ參考トナッタノデアル。

\section{第 3 節 當数室二於ケル種屬特輁性二 關スル業績}

當教室ハ本節二關シテモ可ナリノ賽績キ殘シタルキ誇示シテョイト思フ.

1.上述ノ 2 項ノ如ク, 奥田, 赤松兩氏が圭トシテ概論的事項二主力キ注イダノハ當時トシテ止ムキ

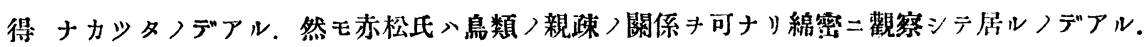

「蛋白免疫反應,特異性二關スル實驗的研究, 特二鳥類ノ種屬特異性ニ就イテ」 ハソレデアル。供試材料ハ可ナリ豐富デ先疫元トシラマ種, 反應元トシテハ9種, ソノ種屬入䳝䌖類, 沜類, 水禽類, 鳴禽類二亘ッテ, ソノ間ノ近親關係 7 詳細二 定ムルコトガ出來タノデアル(免疫獸入家鬼 ヨ用ヒテ居ル). 而シテ血清モ叙上 八如ク含有蛋白量 敦レモ生物學的分類卜近似ノ成績 デハアルガ，山羊對牛，らって對まうす間ノ類族關係ノ檢索二詳細习極メタ. 而シラ抗元トシテハ血清, 血色素ニ止マラズ, 臟器蛂白ヨモ取扱ッラ居ルコト 等八睡二第 1 節二於イテ記述シテ置イタ所デアル。

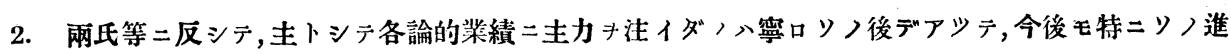
展キ期スベキデアル。コレガ先缏キナシター人トシテ先ジ大㳯氏キ譽グ. 氏八研究對象タル㵶維原素二

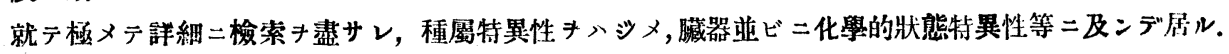

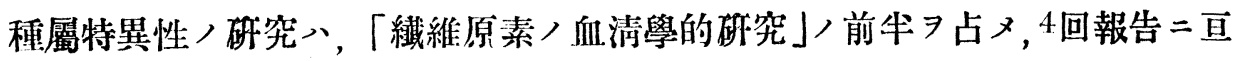
ッテ居ル。牛繊維原素习免没元トシタ家鬼免疫血清二對シ各種動物14種（哺学 類 $コ$ 兩棲類 $=$ 及ブ）八繊維原素反應元 $\ni$ 以テ沈降反應 7 觀察シ, 更二各種動 物纎維原素免疫血清 $=ヨ$ テ各, 間二於ヶル類族反應

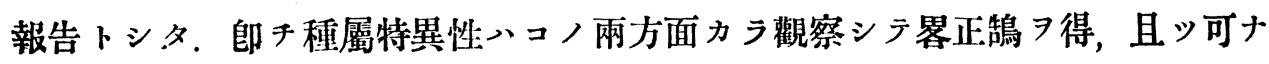
リ顯著ニ現ハソタノデアッ. 多少不規則二類屬反應习呈スル例モアルガ, コレ 八寧口免疫元, 純否二關スルモ, 、如ク, 然モソ, 範圍モ亞目以上 トハナイ。

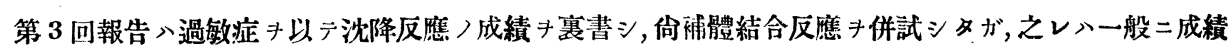

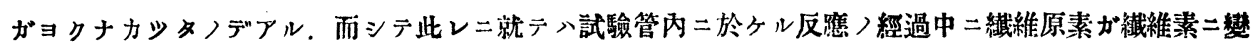

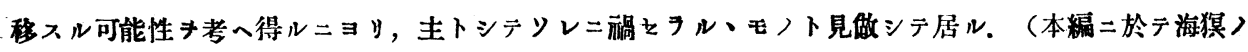


内藤達男連

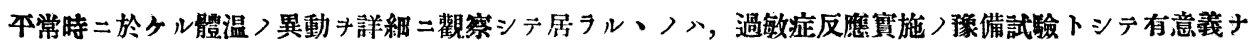
モノデ，特二參考下スルニ足ル）

更二同氏八，特異性制定二際シテ反應要素ノ良否ノ關スル所ガ大ナルニ着目

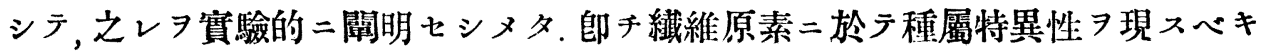
原于團ハ不安定デ變性ニョッテ容易二崩壤シテ特異性 $ン$ 失フガ, 爾餘ノ特異性 低キ沈降性及ビ凝固性ハ佾フル程度迄保持七ラレ得ル．而シラ抗元ノ純否二就 テハ特二先疫元トシテノ㷪合二留意セザルべカラザルェトヨ實驗的 = 立證 シ タ. 茲二於テ余等八，全氏 $=ヨ$ リ抗元ノ純否，戀性ノ如何ガ極メテ重要デ忽諸 ニデキナイコトヨー層深ク學ブヨ得テ，方法論上二於イテ優秀ナ收獲ヨ納メタ ノデアル.

\section{第 4 節 當教室二於ケル裁器特異性二 關スル業綪}

1. 大澤氏八, 更二緎維原素 7 對象トシテ藏器特異性 觀察シタ. 全氏ノ原著 第 6 回報告ハンレデアッテ，先ッ゙血清ト類族關係 觀，ソノ副反應ハ主・シテ ぐろぶりんふらくちおん二因ルコトア明ニシタ. 又抗牛緎維原素㑆疫血清二於 ケル赤血球, 血小板凝集素及ビ溶血素ノ有無 $タ$ 各種動物ノ反應元 用七テ檢シ， 各種抗元間ノ特異性ノ存否习制定スルコトハ出來ナイガ，少クトモ低價ナガラ 各反應二對スル特異性娔疫體，產出シテ居ルコト，郎チ兩抗元二對シテ弱度， 副反應ノ存在スルヨ磪メタノデアル。（松井氏ガ，抗ふいぶらのーり゙ん血清二 テハ血球凝集素ハ溶血素二比シテ强度デ，ふいぶらのーげんハ特二凝集元 有スルコトヨ指摘シテ居ラル、ノハ前者ト對照シテ一考ス心゙キモノガアルト思 ヒ特二茲二附記スル，松井氏原著「抗ふいぶらのーげん血清」參照）。然シテ抗

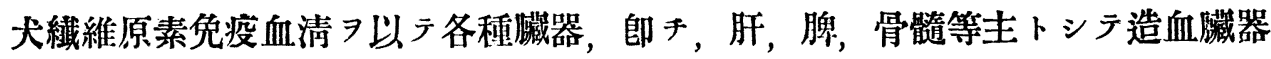

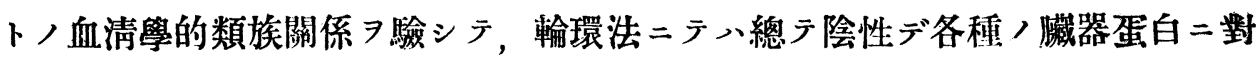
シ明瞭ナ特異性 ヨ示スコト 明ニシタ.

2. 松井氏，血小板ノ血清學的特異性ノ研究」二於テハ,主トシテ血小板ガ 血液諸成分中何レト最モ近キ關係ニアルャ否ヤ，郎チソノ發生學的解决 學的二行ハウトシタモノデアル．牛血小板二就テ，ソノ免疫血清 ツ以ラ赤血球 


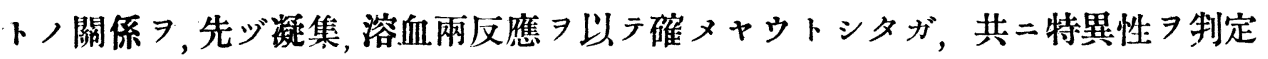
シ難イノデ，更二詳細二兩抗元，分離成分 兩血清反應ニテハ類屬反應ガ强クラ藏器特異性檢甞上不適當デアルコトラ立證 シタ二過ギナイ。而シテ逐二、コノ間，特異性、勿論，一般二藏器特異性ハ沈 降反應 利用スルコトニヨッテソノ目的ヨ達シ, 溶血, 凝集兩反應ノ特異性制 定上意義ノ尠キコトヨ閵明シタノデアル．茲二於テ血清，赤血球，血小板ノ近

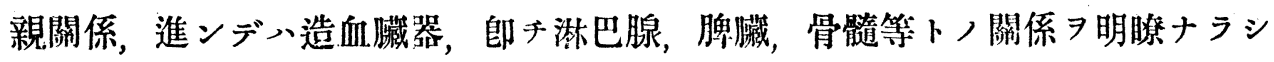
メ，血清トハ親近デアルガ赤血球ト八類屬反應刃゙呈シナイ，又淋巴腺トノ類族 關係八血清卜共通ナ受體二由來シ，ソノ他ノ造血藏器ハ血清トハ無關係二獨爾 ノ副反應ヨ示シテ居ルノヨ觀タ.

3. 次二木村教授,藏器特異性ノ業績 7 簡畧二記述シャウ. 同教授入, “Ueber die chemische Spezifität des Eiweisskörpers II Mitteilung.,, /論著二於テ水

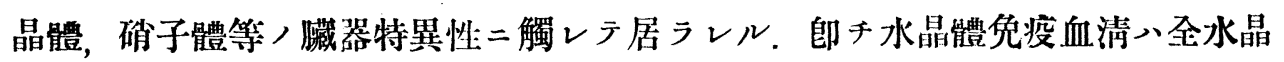
體及ビコノ被膜部 免疫元トシタ鹪合二八, 硝子體, 水樣液等二反應シ殊二後者 ニ於テソノ度ガ强ク，更二核質部ノミノ時ハソ八副反應、微弱デアル。又水晶 體ノ分離成分トシテュノ $\alpha$-Kristallin 及ビ $\beta$-Kristallin 二就テ血清學的特異性

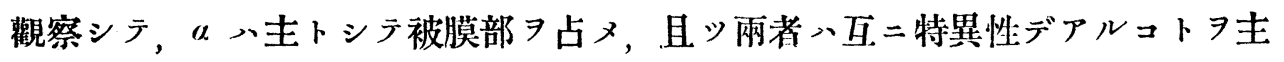
張シテ居ラレル. 又㗂子體二就テハソノ先疫血淸ハ効價ガ一般二低ク，然モ水 晶體, 牛血清及ビ血清むるぶみん，血清ぐろぶりん等二反應シ，又他方二於テ 反應元トシテハ全水晶體免疫血清二對シテ强度二反應 居ラル、ノデアル（總テ供試材料ハ牛

4 , 最後二後藤氏，「水晶體ノ特異性二就テ」ヨ紹介スル。同氏八, 典型卜見

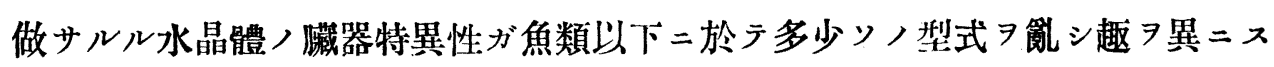

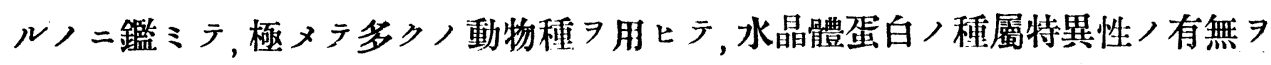
詳細二检索シタノデアル. 而シテ，一見沈降反應二於テ全ク同一程度二反應シ フ特異性 7 見出シ得ナイ鳥類以上二於テモ當該, 網, 目, 科, 屬等每二各獨爾二 共通ナ受體ガ存在スルト考フベキ事實ヨ觀タ, 郎チ水晶體蛋白ハ藏器二固有ナ ル單一受體ヨ有スルノミニハアラズシテ，種屬 タ立證シタノデアル。 
先ヅ各種動物ニ於テッノ各藏器/水晶體免疫血清二對スル特異性キ觀察シテ，僅カ二肝臟二於テ弱度

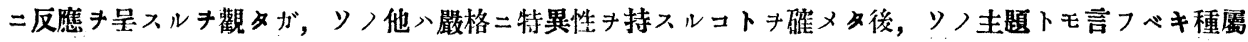

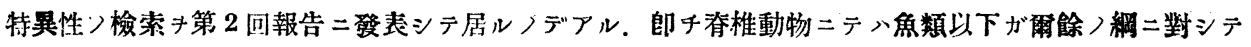

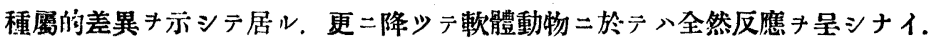

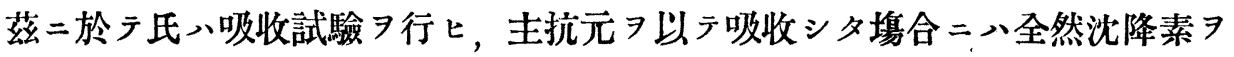
失フガ, 之レガ異種デアル副吸收元デ吸收シタ特二八主反應二八無關係デ, 吸收 元二該當スルモノ及ビソノ所屬綱以下二屬スルヒノガ除去七ラレル。例之，牛 水晶體免疫血清、牛水晶體デ吸收スルト全ク反應 7 失フノデアルガ，馬水晶體 デ吸收スルト哺乳類間，反應心元通りデ，鳥類以下ノモノ、全部失ハレルノデ アル．尙同氏ハ「免疫經過中二於ヶル主副沈降素ノ相互關係」ナル原著二於テ， 魚類水晶體免疫血淸二對シ鳥類，峬嗮類、同程度二反應スルニ反シ，之レガ反 應元タル埃合二魚類水晶體ガ鳥類及ビ哺乳類水晶體ノ怎疫血清二對シ反應微弱 ナルコト、, 免疫機轉ノ進ムニッレ異種沈降素、全種屬二對スル主沈降價二近 ヅキ，種屬特異性ガ不明膫トナル，故二逆二免疫ノ不充分ナ抗血清 八水晶體ニ於テモ可ナリ種屬特異性ヨ觀察シ得ラルル等ノ事實ヨアゲテ居ル。

\section{第 5 節 本 章 ノ總 括}

以上 $ヨ$ 以テ，余入當教室ノ動物性蛋白體ノ特異性二關スル重要ナ業績ノ大畧 ᄏ紹介シ得タト思フ。

清野教授ガ當教室ノ主任トナラレテ，頓ニコノ方面ノ努力ガ積マレタコトハ 泩目二價スル，而シテ再三述心゙タ栐二，同教授ガ遠大ナル抱負ノ下二，規模モ 高大二, 且ッ周到ナル用意ヨ以テ本命題ノ基本 7 碓立セラレタト断言シ得ルュ トハ喜シイコトデアル。

其ノ所產ハ大別シテニットスル. 特異性論究上ノ方法論トモ云フべキモノト, 特異性問題ノ具體的檢素トノ兩者デアルコトハ既述ノ各項二據ッテモ明白デア ツテ, 茲二再ビ詳說スルノ要ハナイガ, 唯前者二屬スルモノヨ次二簡潔二緾メ テ見メャウ.

1. 奥田氏八，免疫血清，特異性ノ强弱卜先疫動物，免疫回數及ビ先疫元， 撰擇トノ極メテ重要ナ關聯ノアルコトヨ實驗的二明示シタ。後藤氏ハ全ジク水 晶體蛋白二於テモ, ソノ動物種ニョッテ免疫原性, 殊ニソノ特異性ノ强弱二差異 
ノアルコト习指摘シテ居ル。

2. 赤松氏八，血清反應二於テン，ソノ反應元ノ量的標準トシテ含有蛋白量 ア整一ニスルコトガ旮モ合理的デアルトノ結論ニ達シテ居ル.

3. 大澤氏八, 血清反應八特異性八如何入，ソ八抗元，純否，變性八如何二 關保スルコトガ至大デ，免疫元トシテ使用スル熄合二於テ特二然りデアルト， 事實 $\rightarrow$ 数一夕.

4. 赤松氏八又, 免疫經過 7 時間的二追求シテ, 免疫回數卜共二特異性八减

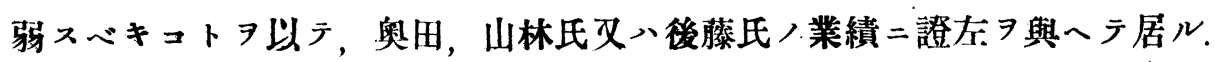

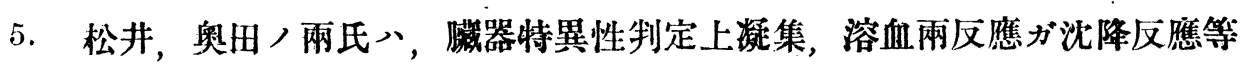
ニ比シチ可ナリ劣レルコトヨ指摘シタ.

以上八特異性研究ノ基礎トナルモノデ，今回ノ瞒器特異性ノ研究ガ之等二據 ル所多大デアッタノハ當然ノコトデアル。

第 2 者二屬スルモノ八, 便宜上第3一4節二分ッラ畧說シテ置イタ所デ,茲二摘 錄シナイ。要之, 本命題二關スル清野教授時代，業績ハ，余等ニトッテハ蜜口創 業特代トモ云フべキモノデ，基礎的知見 7 確立シ，一方從爽ョリ取报ハレタ主 要項目二就テ追試ヨ試ミタノデアル，而シテンノ開拓ガ少十二分デナイコト、 已ムヨ得ヌコトデ，蜜口今後ノ進捗ノ指針トナリ，又基本トナレバ足ルトモ云

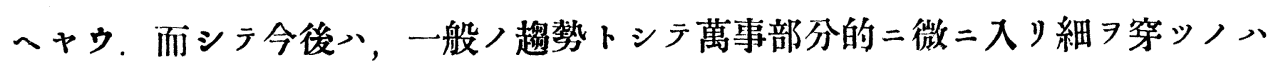
免レナイガ，又總括的檢索モ倘忽諸ニスルコトノ出桃ナイノ八勿論デアル．

コノ機運二際シテ, 宿題「藏器特異性」二關スル研究ガ大規模ニ企テラレテ, ソノ方面ノ出所 $\ni$ 明ニシテ, ソノ成果以外二幾多, 命題 7 殘シテ今後二期待七 ラレタノハ，余等ニトッラ特ニ深イ意義ノアルコト、思フ．此等ニ關シテノ具 體的八考察八後編二讓》, 我田引水 $习$ 打切ッテ, 引續キ内外先進ノ業績ノ一沉 ヨ䉇ッラ見ャウ。

\section{第 2 章 種屬特異性問題八概况}

本章八動物蛋白體二於ケル生物學的意義 ル業績ノ大畧习緾メャウトスルモノデアル。

统體抗元反應ガ特異的デアルコトハソノ當初ニ於テ極メテ驚異デアッタ. 
然シソノ特異性》全然絕對的ノモノデナク類屬反應ヨ呈スル事實ガ見出サレ テ，ソノ鑑别法トシテノ價值ガ多少低下シタコトハ否マレナイガ,他方二於テ， 之レガタメニ却ツテ理論的考察ガ深遠トナリ一段ノ進步 7 來シ, 種屬特異性ソ レ自體トシテモ，生物學上ノ分類トノ對比ニ一層ノ意義 出承ヤウ。

余ハ先ヅ本問題ノ初期 7 回顧シ, ソノ進展ノ跡 ヤウトスルモノデアルガ，全特二今後二對スル指針

本章ハ圭トシテ, Putter >Antikörper gegen Biokolloid 及ビ Uhlenhuth u. Steffenhagen) die biolog. Eiweissdiff. mittels der Präzipitation キ參照シテ記述スルコト、シタ.

\section{第 1 節 種屬特異性問題二就テノ回顧}

種屡特異性ノ研究メ，Fish が牛乳汁免疫血清が人乳及ビ山羊ノ乳汁二對シテ沈降反應キ呈シナイ。 即チコノ間二特異性ノ存スルコトキ見出シタノがンノ滥籍デ, 動物性蛋白體ノ特異性研究りレ自體ノ第 一步デモアッタノデフル。コレニ引續イテ Morgenroth (Ehrlich), Wassermann u. Schïlz が同榡

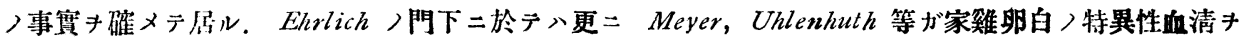

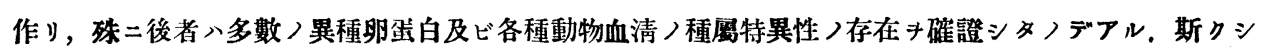
テ Wassermann 等卜共二血液つ法醫學的鑑別法卜云フ賽際的應用二早速ニ利スルコトが出來タ, 引頪

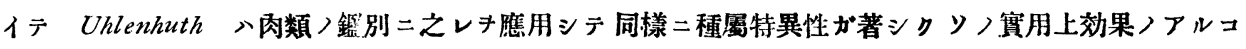
トキ認メタ.

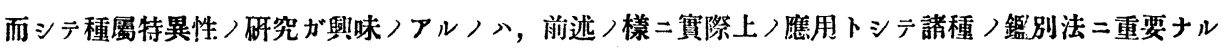

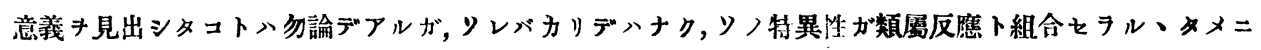

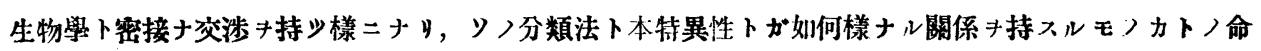

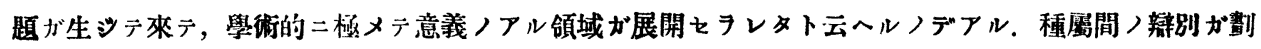

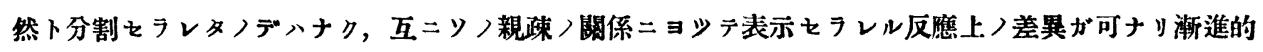

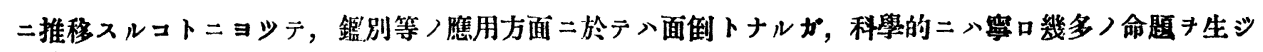
テ興味津々タルモノガフルノデアル。

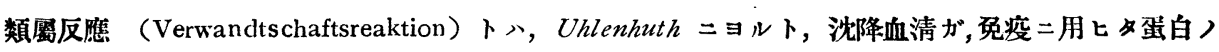
ミナタズ，之レト生物學上近緣ノ動物ノ同種蛋白卜沈降現象キ生ズルモノニ就テ云フベキデアッテ，》

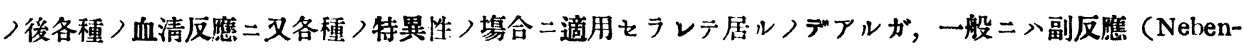

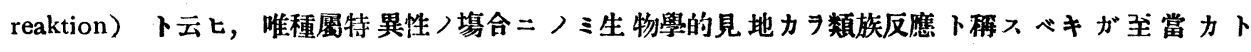
思7.

コノ類族反雇》，當時既二近緣ナ動物群ニヨリテ可ナリ綿密二究メタレテ，ソノ大要ハ盡サレタカノ 觀がアッタ. 例之，人，猿間二於テ、Uhlenhuth，Wassermann，Stern，Nuttal 業鈢キ見ル，侏 
=Nutall 入各種動物間二亘少テ，多數ノ例證キ以テ詳細二類屬關係キ見タノデ有名デ，30 種ノ抗 血清，900種 血波抗元 キ用七テ，1600 ノ反應數ニ及ンダト記載セラレテ居り，殊ニソノ人・猿間入各

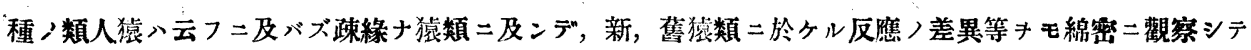
居ル，而シテ成績ハ可ナリ精磪二進化説ト一致スルモノデ，他)三氏卜共=Descendenzlebre(Lamarck，

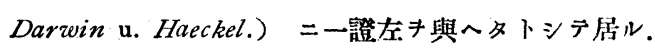

馬, 锰馬, 獏 (Uhlenhuth, Dürck, Weidanz), 犬, 狐, 狼, 砂漠狼 (Uhlenhuth), 橍羊, 山羊,牛 (Uhlenhuth), 豚, 野䀠（Uhlenhuth）等八類屬反應が著明ナノミデナク，時ニハリノ鑑別モ不可能卜ナ シノデアルが，孰レモ生物學的見地ト一致シ互二極メテ近緣ナコトキ明示シテ居ルノデアル．然ルニ必 ズシモコノ所謂生物學的分類法入動物學的觀點ト一致スルトハ云ヘナク，侧之，らつて對まうす間八沈 降反應キ以テスルモ補體結合反臨キ以テスルモ,容易二雨者キ分ッコトが出來ル.即千血清學的二八兩者 ノ近緣關係入著明デナイトサレテ居ル。（Uhlenhuth u. Weidanz, Trommdorff, Grätz, Steffenhagen u. Schönburg, 向前章/奥田氏/項參照). 而シテ當時/類族反應〉檢查入, 所謂 Mammalian reaction (Nutall) 二止マラブシテ，既=魚類 (Neresheimer, Dunbar, Kodama) 及ビ兩悽類 (Dungern, Galli-Valeris, Jochmann, Nutall, Smith) ニ及ンデ居ルノデアル。本節ハまトシテ Uhlenhuth >訅載 $=ヨ$.

\section{第 2 節 類屬反應二就テ}

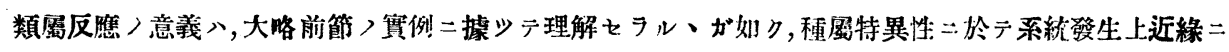
アル動物蛋白體が互二血清學的二關聯ノアルコトキ示スモノデ，相互二共通ノPartigen 群キ有ス卜見

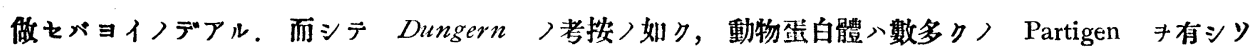
レが全體トシテ種屬特異性キ示スモノデ，而モソノ個々ノ受體ハヤハリ系統發生學上二獨雨ノ意義キ有 シデ缺クコトノ出來ナイ關聯キ持スルノデアル，即子類臀關係が近イホドンノ共通受體か多ク，相互

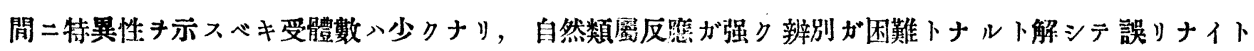
思 7 .

而シテ類族反撨入學術的見地ヨリハサテカキ，特二賽際㫿用上少ナカラメ障害トナルモノデアリ，叉

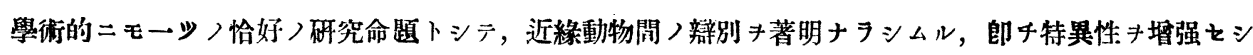

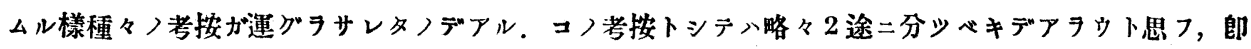

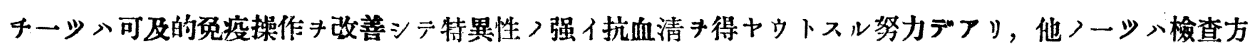
法ナル血清反應自體ニ種々ノエ夫キ凝ヨサウトスルノデフル。

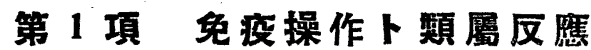

1. 先ヅ Uhlenhuth ガ交攵免疫法 (Kreuzweise Immunisierung) ニョッテ, 近緣間二特異性㧤疫血清 ノ辨別 ヨナス ，先疫獸 家鬼トスル時ハ類屬反應ガ著シク，ソノ辯別容易デ 
ナイノニ反シテ, 人血 $\ni$ 猿二泩入シテ得タ免疫血清入人血二特異的デ猿二ハ反 應シナイノデアル．此ハ前述ノ受體 ノモノ八共通受體ガ多ク，凭疫元トシテ作用スルモノハ少數ノ共通デナイ受體 デアッテ，ソレニョッラ特異性免疫血清ガ生ズルノデアル．全樣二家雞對家鳦 又、野鬼對家鬼ノ間ニモンレガ可能デアッタト云ハレテ居ル。

出口氏 $モ$, 亦人血卜和猿血卜ノ間二於イテ交文允疫 $\ni$ 行 $テ$, 抗人血和猿血清 八猿血二八作用シナイガ，他八動物二八强度二反應スルコトヨ認メテ居ル。

然シ受體鿁キ以テスルモ，力、ル操作ニ於イデ，有効ナ受體ハ少數ナノデ，ソノ抗血清ノ微弱ナコ

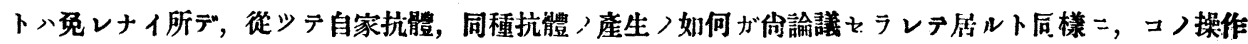
が必シモー般二容易二適シ得ル重賔ナモノダトへ云へナイ。ソレ所力Biondi，Nolf，Schur 等八交 议免疫法二成功シ得ナカッタコトキ報告シ，特コソノ近緣關係ノ著シイモノホド不可能デアルトシテ居 ル，又 Uhlenhuth u. Steffenhagen こモ本法が必シモ交互二可能デアルト>断定シテ居テナイ.

殊二最近 Vhlenluth 八菼刃免疫法二於イテノ永年ノ觀察习總括シテ，ソノ可 能性ガ寧ロ少イコトタ認メテ居ル。即チ全氏ガ人血/鑑別上用ヒタ猿ハ下等， モノノミニ於イテ成功シタノデ，其後類人猿 鑑別ハ必ズシモ容易デナイ。カ、ル事實、野兔對家鬼，山羊對羊，馬對䮡馬等 ニモ言へルノデ一般二成功シ難イノデアル，勿論當先疫獸ガ生來泌降素產出ガ 微弱ダト云フコトモ關係スルコトヨ考へネバナラヌシ，又各種間ノ秏族的差異 ガ混入スルタヌニ不明暸トナルコトモアルトシテ居ル

2. 次ギ二免疫操作ノ改善トシテハ,殊二免疫度ノ强弱, 及ビ免疫動物種ノ主 副反應二及ボス影響デアル。共二當教室奥田, 赤松, 山林氏等, 業績二大要 7 窥

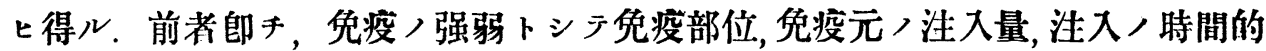
間隔等ガ意義ノアルコトハ勿論デアルガ, 就中, 仯疫回數ト抗血清探血日二泩意 ヨセネパナラナイ。一般二泩入量 7 增シ, 泩入回數 7 重六, 且又抗體產出ノ最高 期ニ至ルニ從ッテ, 副反應ガ主反應ノ增强ニモ優ッテ, ソノ度 ヨ加へルガタメ 主副ノ差ガ微弱トナルノデアル．故二，例之赤松氏ガ血清ノ免疫、1 回泩入後 13日目 略々最適トシテ居ルノハコノ理ニ據ルノデアル (Manteufel u. Beger 操氏照）。後者、免疫動物ノ選擇デアルガ，總ジテ免疫効價ノ如何ガ免疫獸 ニ關スルコトガ著シイノ八既二交铍先疫ノ所デモ注意シタ所デアル. 
(2526)

免疫上家鬼が最艮ナノ八論ズルマデモナク周知ノ事實デアルが, 家䌖ナドモ可ナリ使用シ得ルモノデ アル. 然シ以上ノモノデモ種屬ノ差, 或又個性ノ差異等が案外强ク影響キ及スモノデ, 必シモー定二八行 カナイノデアル (Friedberger u. Jarre, Krutter). 抗體産生能ノ少ナイモノトシテハ犬(Ficker, Friedem-

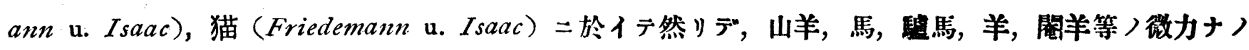
、Uhlenhuth モ指摘シテ居ッ. まjす (Trommsdorf Ritz), らつて (Dehne u. Hamburger) = 於イテハ全ク産生キ見ナイトモサレテ居ル.

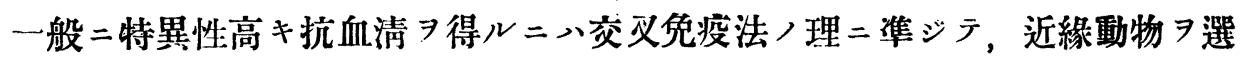
ブハ勿論デ，親近ナホド效價，低イノ免レナイガ特異性ガ著シク，コレト反 對二類屬反應习著明ナラシムルタヌニ入遠緣ノモノフ選ブベキデアルガ, 先疫 獸 又一般二生物學的分類上/高下二從ッラ抗血清, 銳敏度卜特異性二モ相違 ヨ來タスノデァル，即テ高等動物ハ一般二特異性 ヨ著明二現シ，下等ノモノ、 類屬反應ガ著シクナリ特異性入微弱トナルノデアル（奥田氏）.

3. 危疫二用フべキ免疫元，選擇ガ重要ナコトハ云フマデモナイ，當教室ノ 大澤氏ガ，前章二於イラ述ベタャウ二，免疫元／純否變性ノ如何八特異性ノ制 定上極メラ重大デ，ソノ如何ハ反應元ヨリモ遥二意義ノアルコトヨ指摘シテ居 ラル. 又後藤氏八, 免疫元トシテ用フル全一贜器モ, ンノ動物種ノ高下 テ，特異性ノ度二差ガアルモノデ，下等動物ノ水晶體入他種二對スル共通受體 ガ少ナイタメ種屬的二特異性ガ現レ易ク，鳥類以上ニ於イテハ分化ノ進ムニッ レ共通受體ノ多キタタ種屬特異性ガ覆レルト云フ事實ヨ認メラ居ル。

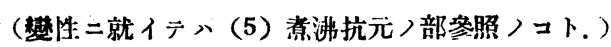

4. 免疫元二人工的操作 7 加へラ特異性 7 顯著ニシャウト八試ミ，內, 最モ 穞和ナ方法トシラ八, 該當スル抗血清ヨ以ラ吸收シラ抗元 トスルノデアル，一體，抗元入外因二對シテ可ナリ抵抗スルモノトセラレラ， 種々ノ操作ガ加へラレテ居ル. 然シ，一般二抗體產生能二差シタル相違ナキヨ 以テ直テニ抗元二變化ガナイト入斷ゼラレナイノデ, 容易ニンノ與相入捉ミ得 ラレナイノデアル

先ヅ, 抗血清ヨ以ラ純化シャシトスルノ試トシテン, Weichardt /飽和吸收 法ガンノーッデアル. 即チ, 當該抗血清 $コ$ 以テ抗元中ノ餘分ノ受體 ヨ吸收除去 シャウトスルモノデアルガ，抗元抗體，吸收操作ニ於イテ抗體即チ抗血清习多 
量二要スル不便ガアリ，又抗元，沈降能ガ微弱デアルカラ，自然，抗元二對ス ル種々ノ附加的要約ガ重ナルノデ,考按トシテ八面白イガ餘り利用セラレナイ. 鳥潟教授ノ特異沈降子入, 前者ニ反シテ, 抗血清 收集シラ造抗元トシラ用フルノデアル.本法モソノ考按ハ妙デアルガ，奥田氏 八追試ヨセラレテ，効價及ビ特異性共二著明デナイトシテ居ル。コレハ，沈搌 子ノ大部分八理論上抗血清ニョッテ占メラル、コトガ多イトノ理 スルコトガ出來ヤウシ，又沈澱子，货疫能力八微弱ナノニモ因ルモノデアル。 以上二者八實際上餘り利用セラレテ居ラナイ。

5. 煮沸抗元二就イテハ, 鳥潟教授ガ, 既二細菌二於イテ賞用シラ居ラル、所 デ，㟟沸允疫元／優秀ナルコトヨいむぺ゙ん現象 ヨ以テ說明セラレテ，こくち げんトいむぺぢ學說ト八學界二重キヨナシッッアルノハ周知ノコトデアル。 動物性蛋白二於イテノ藤原氏，煮沸凝固抗元八全巧異曲デ，氏ハ之レヨ以テ補 體結合反應ニテ人・猿ノ鑑別二優秀ノ成績 者ガ出デラコノ方面八極メラ盛况习呈シテ來タ.

一體抗元二對スル熱ノ影響トシテハ，古クハ多ク反應元キ對照材料トシテ論シタモノが多イ，例之，

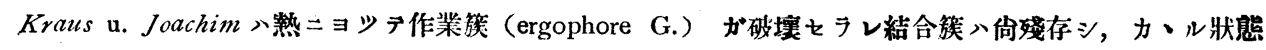
ニ於イテモ，佾ヨク沈降素キ形成シ得ルト云フテ居ルノデフル（Eisenberg, Doerr u. Moldovan

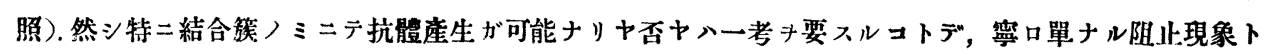

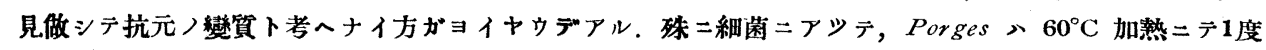

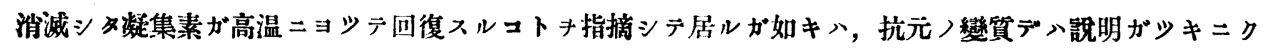
亿. 然シ他方動物蛋白二於テハカ、ル低温二於ケル阻止域キ示メサズ, 單二漸進的二抗元性キ减弱シ行 クノキ見ルノミデアル。鳥潟氏 $\mathrm{z}$, 一般二細菌性抗元八熱二抵抗强ク,動物性蛋白八弱イト指摘シテ居》

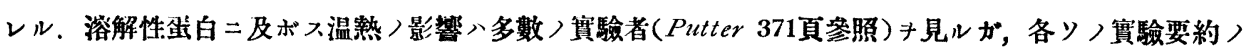

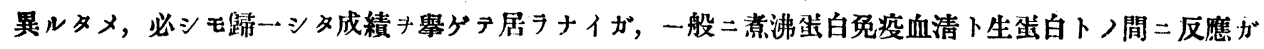

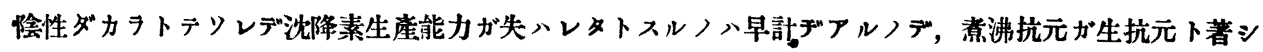
クリノ抗元ノ特異性二相違ノアルコト入 Obermayer u. Pick, Sehmidt, Chapter 等ニヨッテモ訅述を ヨレテ居ルがー方二於イテハ更二生蛋白ト干作用スルコトが認メラレテ來テ，遂二種族特異性入却ッテ

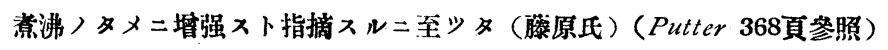

引續イテ Fornet u. Müller $>85^{\circ} \mathrm{C} 5$ 分加熱ニョッテ効價モ高ク特異性モ著明デ アルコトヨ認メ, 多少状態特異性 ガ, ソノ制別、容易デアルトシテ居ル，Beger ハ牛對馬，馬對羊等ノ多少遠緣 ノモノ二於イテ良好デアッタガ，人・猿，馬・驢馬二八意義ガ少ナカッタトシテ 
居ハ，田口氏，新井，小西氏等モ追試 免疫血清二依ル心キモノデアルガ, 惹沸扰元ガャハリ有効ナコトハ認メテ居ル. Manteufel, Rosenberg, 等モ最近二於イテ共二有意義ナコトヨ認メテ居ル.

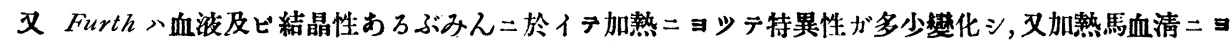

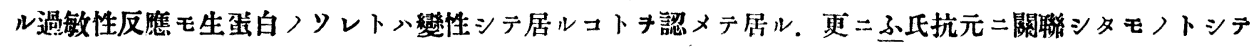

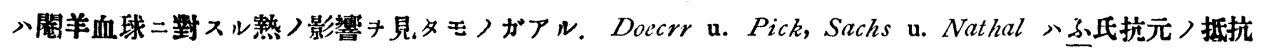

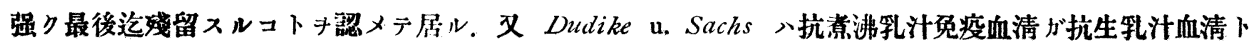
暴リ，血清二對スル副反㗹ノ現レナイコトキ認メタ。

斯クノ如ク煮沸抗元ノ研究、細菌二於イテノ鳥潟氏ト共二，動物蛋白二於イ テハ藤原氏，考按ガ斯界二重キヨナシテ居ルコトハ特筆ス心゙キコトデアル。

6. 前者ト關聯シタモノ二「熱あろから抗元」ナル考按ガアル. Schmidt $=$ ヨッ テ提呾セラレタモノデ, 抗元ハス心゙ラ加溶性デナケレバナラナイトテ,一度者沸 凝固シタモノタソノマ、デハナク，あるかりニテ處理シテ溶解スルコトニヨッ テ更二有効ナラシメタノデアル，氏ハ血清, 肉類二於イテ狀態特異性 7 有シテ, 生蛋白トハ作用シナイガ種屬持異性、ョタ保タレテ居ルト指摘シテ居ルガ，堺 氏ニョルト熱あるから沈降素、高温加熱蛋白ノ鑑別二有効デ，ソノ高價ナ時二 八生蛋白ニモ反應スルコトガ確メラレタ. 又前述ノManteufel, Beger, Roserberg

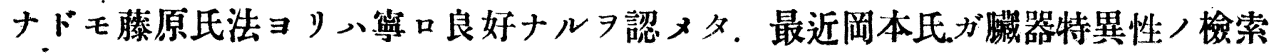
二用ヒテ極メテ良イ結果ヨ得テ居ル。

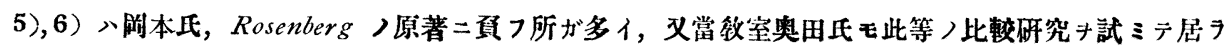
ル，孰モ参照スベキモノデアル。

7. 酒精ニョッテ㔻白體 フル所デ,、ソノ抗元二對スル影響モ少ナイト見做サネバナラナイ。而シテ本項

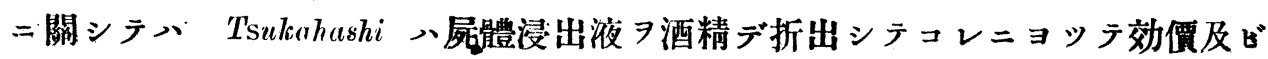
特異性共二優秀十抗元 得タトシテ居ルカ, Manteufel u. Tomioka モ全樣ノコ トヨ云ヒ, 新井, 小西氏 Scimone u. Torii 等ハ之 擧ゲテ居ル.

8. 最後二乾燥抗元二就イテー䁈シテオカウ, 血液等ノ抗元ガ乾燥二涌へ得 ルコトハ早クカラ氣付カレタコトデアル (Schmidt, Löffler, Wissmann)。 ソレ所 カ特異性ガ强イコトハ煮沸抗元二倣フモノデ，例之，小南教授及草刈氏等八乾 
燥A血ガ却ツテ沈降價モ特異性二於イテモ著明ナル抗血清

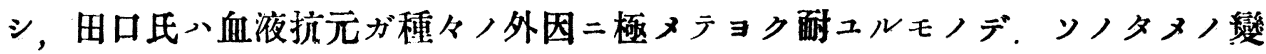
質等ニ就イテモ詳細二檢甞シ玄居ル。

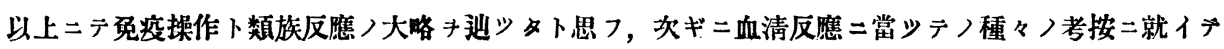
述ベヤウ，コレキ大略免废血清/特異化法卜檢查方法上ノ考按卜ノニッニ分ッコト、スル。

\section{第 2 項 免疫血清ノ特罢化法}

免疫血清中ノ副抗體キ除去シテ特異性血清シ得ヤウトスル試ミデフル，之キ試铪管內特異化法卜生體 内特異化法卜ノ二者二大別入. 後者八最近 Linossier u. Lemoine, von Dungern, 小口, 西尾, 繁藤 氏等コヨッテ生體内二於ケル抗體抗元/共存問題が䐙明をラルルー方二於イテ，操氏ニヨッテ考按命名

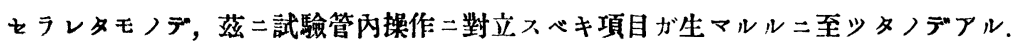

1. 試驗管內特異化法中有名ナモノ、Weichardt ）飽和吸收法 (Absättigungsverfahren）デアル. 此レハ Ehrlich u. Mor!lenroth ノ所謂 elektive Adsorption ノ原理二則ッタモノデ，細菌性凝集素ノ特異化法デアル Castellani 氏法卜全趣 巧デアル. 既二Ascoli, Michaelis, Bertarelli 等ニョッテ各血清ふらくちおん 等ノ辦別二ハ用ヒラレテ居タガ, 種屬特異性二於テ利用シタノハKister u.

Weichardt 二始マル. 即手類族反應、，ソレ二該當スル副抗元ノ適量 $习$ 混加 シテ，相當スル副抗體 ヨ特異的選擇的ニ飽和吸收スルコトニョッテ除去セラレ ル, 要スルニ Partigen $ヨ$ 以テ飽和シ去ラウトスルニアル. 而シテ Weichardt ハ本法习以テ人・猿間ハ勿論, 個性的差異 モモ辦別シ得タト云ッテ居ルノデア ル.ソノ他 Fiirth，藤原氏等モ之レニ讃シテ居ル．

奥田氏モコ)方面二檢索キ試ミテコ〉價值キ認メテ居ル。然シ本法玉必シモ完全ナモノデハナク，り 〉効果ノ思ハシクナイコトモ少クナイ (Obcrmayer u. Pick, Mertens, Strub, Beger etc). コ/點入本

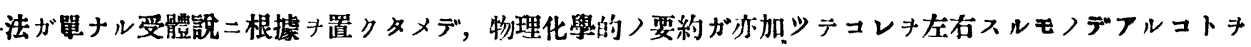
モ併セ考へネバナラナイ，殊二復抗元二テ受體多シト考へヨル、モノニハ，特二，ソノ感が梁ク，藏器

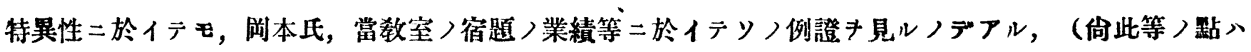
後編二於イデ詳細二論バベシ．添化スル吸收元ノ量二就イテハ奥田，操氏等ノ業績キ參照スルトヨク， 後者ハ大量キ用七テ勃果キアア゙テ居ル。)

吸收元トシラ普通二用ヒラレルノ八當該血清デアルガ，茲二血清二對スル副

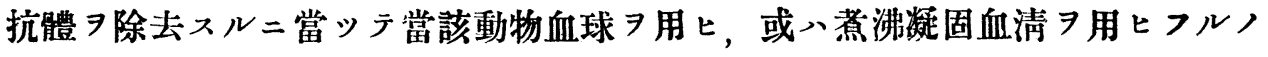
エ夫ヨ凝シテ居ルコトガアル，此レハ Friedberger一派ノ考按デアッテ，血球 
ヨ用フルハソノ科量及ビ後處置ノ遠心沈澱二便宜デアルトシ，又薏沸血清二テ ハ全ジ理由二據ルモノデ，然モ之レヨ以テ主抗元 $ヨ$ 吸收元トシテモ少副沈降素 ノミア除キ得タト云ッテ居ル. Manteufel u. Beger, Beger，等ハ之レ二賛全シナ 1. 藤原氏八者沸凝固血清 9 吸收元トシテ補體結合反應二對スル特異性二成功 シテ居ル. 少 Braun ガ, 凝集セル菌ハ抗血清成分,殆ンド全部ヨ共二吸收シ テ居ル事實カラ, 吸收スベキ抗元二該當スル動物種 ツテ凝集セル菌塊ヨ加へラ゙沈降素, 過敏症抗體等习除去セシメ得テ居ルノデ, コレニ據ル副受體除去ノ考按モ生ズル，（須賀氏参照）

飽和吸收法二就イテ更二考按セタレタノメ，鳥鼬教授ノ沈激外結合法デアル。此レハ沈降元卜同抗體 ノ結合八不可視域二於イテ佾著シ.イモノデアルトノ理ヨリ，十二分二吸收をシムルタメ多量ノ吸收元 *

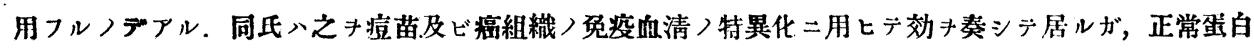
二應用シテ効果がアルカハ未知數デアル．（コノ點二就デ奥田氏/原著參照）

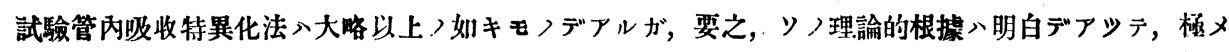
テ巧妙ナ考拨デアルが，賽際上多少ナタズ難點キ見レモノデアル。即千吸收が十分二行カナイコトがア

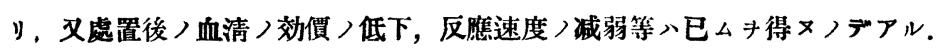

最後二島潟氏／加熱特異化法キ加へテ置力ウ，即子前述／如ク癌組織及ビ痘苗免疫血清キャ、高温二 非働化スルコトニヨッテ特異化サレタト云フノデアル. 本法モ办動物性正常督白二モ適用シ得ルカハ今

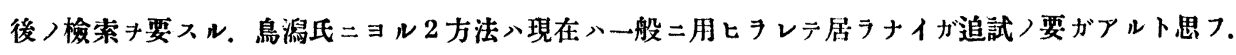

2. 生體內飽和吸收法. 本法八操氏ノ新考按ニョルモノデ極メテ良好ノ成績 ヨ擧ゲテ居ル．上述ノ如ク生體內二於ケル抗元抗體，共存問題ガ略否定二傾イ タト全特二, 一方之レ二關聯シタ工夫ガ生ジタモノト云ヒ得ルノデ，理論的解 决ト實绦的應用トガ一致シタ譯デアル。操氏ハ牛對山羊ノ鑑別ニ於イテ副沈降 素 泩入シテ, 特二 $2-8$ 特間以内二於イテ副沈降素ガ圭トシテ除カレテ特異 性血清ヨ得ルコトガ出來タノデアル.

最近ノ須賀氏ノ追試ニョルト，吸收特異化ハ可ナリ嚴格ニ行ハレテ，然モ主 反應ノ沈降價, 低下, 反應度, 减弱等,䔩害 $\exists$ 除クコトカ出來, 殊二大量ノ特 異化血清 所デァル．本法ニ關シテハ，又既二小口及ビ演野兩氏ガ血清各ふらくちおんく 特異性ノ檢甞二利用セラレテ, ソノ効果 7 賞讃シテ居ラル、ノデ, 今後本法二 ヨリ本領域ガ劃段ノ進步ヨナスコトハ望マシイコトデアル. 


\section{第 3 项 檢查方法上二於ケル考披}

特異性制定二於イテ最後ノ鍵ヨ握ルモノ八檢查方法自體デアッテ，從ッテ本 項二於ケル考察ノ忽ニナラナイノハ刎論デアル。然シソノ進步ハ必シモ著シイ トハ云へナイ，例之，沈降反應ハUhlenhuth，Nutall，Ascoli $ヨ$ 出デズ，補體結 合反應モ Bordet et Gengue, Sachs u. Neisser. ヨ出デナイノデアル.

ソノ主ナルモノトシテハ, (1) 檢查方法ノ選擇, (2) 檢查術式ノ改善デアル.

（1）檢查方法ノ選擇，現今當佮題二於イテ用ヒラレルモノ八主トシテ沈降， 補體結合反應デアル．而シテソノ何レガ本目的ニ適シテ居ルカハ盛ンニ論ゼラ レタノデアル.

沈降反應ガ簡便デ，割合二銳敏デ，且ッ正確デアルノハ確カデアル．然シ補 體結合反應が更二銳敏デアリ，顯著ナ特異性 示スト主張スルモノガ少クナ イ。例之, Bauer, Bruck, 柴山，藤原氏等入人・猿ノ鑑別习容易ナラシメ，Seiffert, Grätz, Rickmann, Bauer 等ガ各種動物間二於イテ，ソノ事實 認メテ居ルガ 如キデアル，Friedberger 等モ亦，異種反應ノ除去上補體結合反應 居火

少過敏症反應二於テハ、ソノ操作ノ困難ナタメ檢甞必シモ充分デナイ．殊二 ソ八量的關係 $コ$ 定ムル上ニ於イテ不便ガアルメメ，比較試驗二八正碓 タイ. Pfeiffer 或、三田氏ガ或ハ泩入量ニョリ, 又八體温〉變化二圭キ ソノ精密ヨハカラレタノハ一段〉進步デアルガ，實用上佾幾多ノ難點ガアル. 要之, 實用上不便ナコトハ他ノ2反應二數倍スルノデ，之レガ特異性制定上特殊 ノ意義 ヨ有スルカ否カデ實用上ノ効價值モ定マルモノデアラウト思フ。然シ, コノ點二就イテハ必シモ明膫デナイ。

沈降反應卜，優劣異全二就イテモ必シモ定カデナイヤウデアル．最近二於イ テ Otto u. Cronheim, Schwarzmann ガらって，まうす，或又人・猿間〉鑑別等 ガ受動性過敏症反應ニョッテ他ノ反應ヨリモ秀レタ成績ヨアゲタトシテ居ルノ 八渡邊助敎授ガ特ニ泩目セラレタ所デアル。

今之レニ關スル糜史的二有名ナモノ 


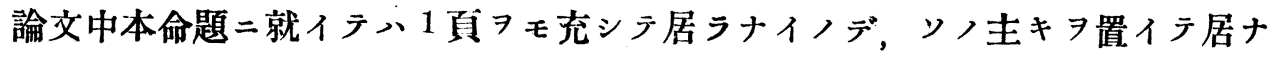
イコトガ分ル。

Otto ガ抗馬血清免疫血清が他動物 血清二對シテ特異デアルノシ見出シタ,が創始デアルトセラレテ

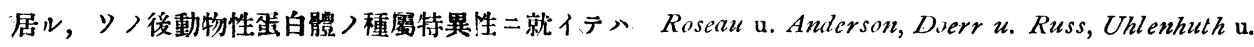
Haendel, Pfeiffer, Arthus, Andersohn u. Hrost, Ninni, Bachrach, Coporalli, Thomsen. Sleewsijk, Friedberger u. Mita, Minet u. Leclerg 等ノ業績が擧ゲラレテ居ル.

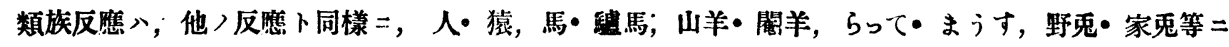

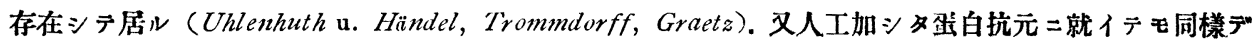
アル (Uhlenhuth u. Händel, Misnert, Mione u. Leclerg etc). 倘注意ス心゙キへ Trommsdorff へ, らつて・まうす等ハ他ノ反隹ニテ分類影著ナル二過敏症反應ニテッコレキ區別スルコト出來ナイ．而シ テリノ因ハ本反箩ノ微妙ナルニアリトシテ居ル。

類族反照入定量的測定法デ制定出來ルノデ，又リノ意味カタシテ受働性過敏症がョイトハ，既二 Doerr u. Russが指摘シテ居ル. 向一方抗過敏症現象キ以テ人・猿, 家兔野鬼間著明ナタシメタが, 人トちんばんじー間二ハ成功シナカリタ (Uhlenhuth u. Hündel, Yamauchi). メ. Pfeiffer 八體温測定 法ニョッテまうす・らって間二量的差異㒛メタ. (Doerr m Koll-Wass. HB. I Anfl, Bd II S. 989)

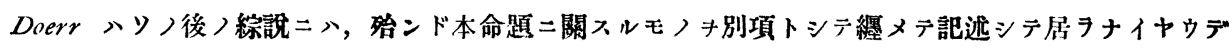
アル.

最後二石原氏が Abderharden 氏法キ利用シテ人・猿，牛・馬，家兔ノ血清爁別及ビ牛馬及豚ノ生肉 及ビ鑵詰肉ノ鑑別二成功シテ居タルルノメー顧二㵋ス。

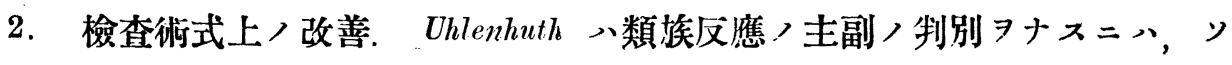
ノ効價ノ高低 以テ定ムベキデアッテ，從ッテ，ソノ對照二泩意スベキュトラ 教へテ居ル，而シテ數量的標隼ト共二反應, 强度, 殊二速度二留意シテ, 短特 間二生ズモノノミヨ全種沈降反應ト見做シ，時間ノ崌レテ出現スルモノ八異種 或ハ非特異性反應卜見做シテ居ル，又非特異性反應＼cjkstart强イ抗血清、全ク使用二 酎へナイコトモ泩意シテ居ル。 カ、ル留意ノ下二於イテハシヌテ幾多ノ特異性 、確定セラレタノデアル。沈降反應、約二十分特迄ノ結果 ノナリトノ規隼モ亦茲二存ズルノデアル。

Hamburger 八又山羊・牛・羊三者間ノ鑑別二，三者二對スル効價ノ相近イ 免疫血清 $\ni$ 選ンデ, 各二對スル各反應元ノ反應ノ程度 $\ni$ 比較シテ, 容易二三者 ノ特異性ヨ見出シ得タノデアッテ，之レニョッテ近親ノ間二於イテハ相互二血

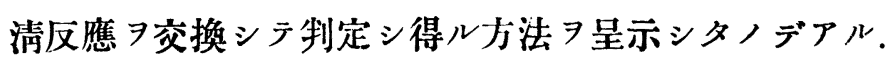

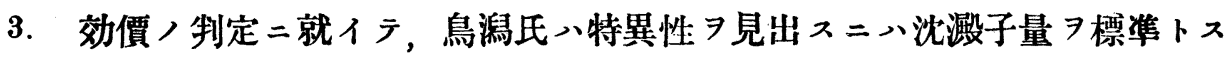


ルノガ合理的デアリ，又實際上秀レテ居ルト主張シテ居ラレル，綿密ナル計量 法トシテハ, 古ク, Nuttal モ考察シテ居ルガ, 鳥潟氏ノ沈澱計二依ッテ始メテ 實用化セラレタモノデアル。 シカシ本法ハソノ術式ノ面倒ナノト供試材料多量 ヨ要スルヨ缺點トスルモノデ，慣用ノ輪環法ニテ充分間二會フ㰾合ガ多イノデ アル．又果シラ雨者，何レガ優レラ居ルカハ當方面デハ今後ノ問題デアル，藏 器特異性二就テ今回三好氏ガ試ミラレテ多少見ルぶキ成績アアゲラ居ラルコト 八後述シャウ.

最後二Friedbeger 一派, 人々ガ, 主トシテ異種反應二就イテデアルガ, ソ ノ辨別ノタメ, 沈澱子ノ稙子, 性状二泩目シ, 或又, 二重輪環 ヨ考察シ, 更二 Stälketiter u. Massentiter 賞用シタルガ如キモ, 亦本項二關聯スルモノデ今後 ノ研甞ニョッラ益々ソノ意義ヨ大ナラシヌタイモノデアル。

\section{第 3 節 異型反闡二就 テ}

特異性血清入前節ノ如ク類族反應キ呈スルベカリデナク，更二生物學的見地カラスルト極メテ疎緣ナ モノノ間二反應キ呈スルコトがアル，カ、ルモノキ一括シテ異型反焦トシテ茲二遮ベテ見ヤウ。（本節 メ圭トジテ Putter，記述二從フ.)

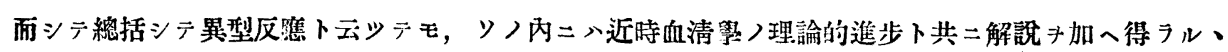
モアリ,一檒メトシテ論究スベキモノデハナク,ソノ研究推䔟二從业テ, 非特異性反應 (Aspezifische Reaktion) 卜異性反應（Heterogenetische Reaktion）ノ2 項二分リノが至當デアルトウデアル。

\section{第 1 項 非特異 性. 反應}

既二 Uhlenhuth ガ血清反應賽施中二非特異性反應ノ出現スルコトヨ指摘シ テ，之レハソノ檢查方法ニ綿密ナル泩意 スルコトガ出來ルカラ, 特ニ榄降反應ノ實施中二泩意スベキモノデアルコトラ 述心゙居ル.生物學的二極メテ疎緣ナ蛋白二對ンテ反應 Strube, Kister u, Wolf, Kratter, Nuttal ノ記述二モ見ルコトガ出來ル. 其後本 佮題、餘リニ泩意セラレズ，又特二深イ討筲 Friedberger 氏一派ガ再ビ泩意习随起シタノデアル.

Friedberger u. Meissner, Friedberger u. Jarre, Meissner 等八, 此非特異性反隹)存在が可ナり類慗

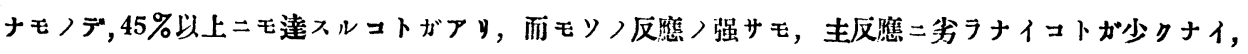




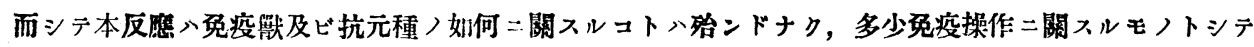

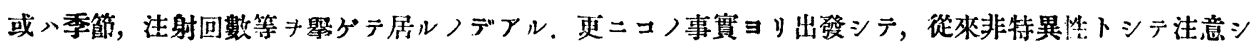

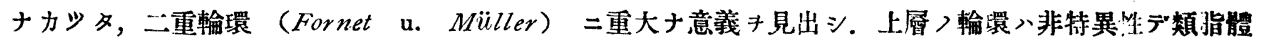

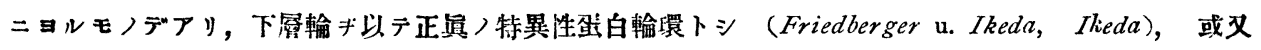

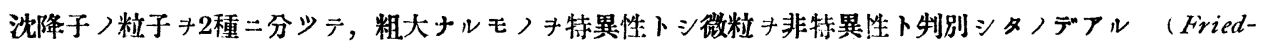
berger u. Meissner). 向免疫血清キツ/免疫元及ビ特異性/如何ニヨッテ, 免疫元/純一ナルキ “Mono

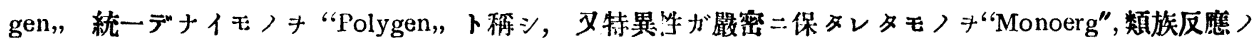

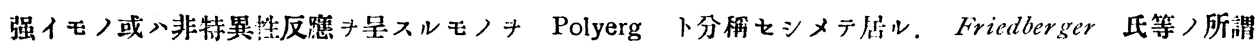
非特烡性反隹入 Mongen-Polyerg 二屬スルノデ，特異性执血清ハ扬論 Monogen-Monoerg ナルベキ デアル (Friedberger u. Meissner).

斯クノ如ク非特異性反應ガ可ナリ頻出スルコトハReesers ニョッテモ泩意セ ラレテ居ルガ, 一方二於イテ Nenmark u. Gutfeld, Manteufel u. Beger 等、 コレヨ承認セナイ，然シ Friedberger 氏等八更ニコレ等 Reaktion ニ結ビッケテ觀察习進メテ居ルノデアル.

\section{第 2 項 黑 性 反 應}

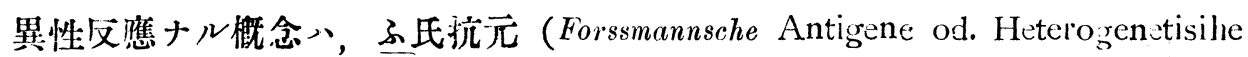
Antigene），開明ニョッテ，一見非特異性ト見ラル、反應二重大ナ意義 7 附與 シタコトニ始マルノ八周知ノ事實デアル。而シテ落ニハふ氏抗元二就イテ解說 ヨスル必要モナク, 对ノ餘裕モナイガ, 動物分類上極メテ疎緣ナモノ，間二共 通ナ抗元ノ存在 $\ni$ 確證シテ，一見無意義ノ如キ血清反應 7 意義アラシメ，且ッ 化學的方法ニヨッテ，ソノ本態 $\exists$ 究明スル 得テ，や氏反應等，所謂非特異性 反應ノ理論的考察二光明 與へタコトハ大ナル收穫デアル.

略言スルト，及扰元卜ハ生物學的見地トハ全ク無關係二動物間二度ク配在

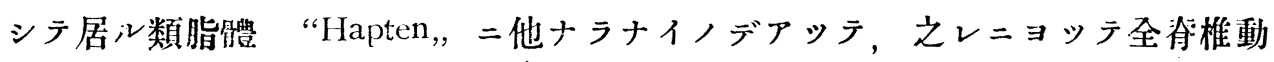
物、家鬼型及ビもるもつと型二分括セラレタノデアル（Bail u. Margulies， Friedberger).而シテふ氏抗元、筒羊血球 7 對照トシテノ考按デアルガ (Forssmann Orudschiew)，少ソノ對照 7 異ニスルコトニヨッテ異性抗元モソノ數 7 加フ べキデハナカラウカトノ推論、容易二考へ浮ブコトデアル，例之，Kritschewsky ノ如キハ家䌖血球二對スルモトシテ，全氏命名ノ抗元 7 認メテ居ルガ如キデア 
ル．系氏抗元ガ又貚二閶羊血球八溶血作用二關與スルノミデハナク，補體結合 反應、勿論, ソ/他ノ血清反應二關與スベキコトモ亦論究セラルぶキ題材デア N. (Sachs u. Guths, Taniguchi.)

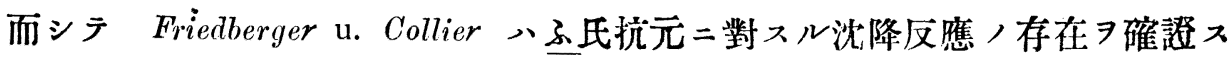
ルニ至ッタノデアル．即手抗馬家鬼血清ガ闇羊血清二對シ高度二反應シ，又ッ ノ他二對シテモ副反應 於イテン，コノ事實习認ムルコトガ出來ナイシ，殊ニコ／異性沈降素八閶羊血 液ヨ以ラ飽和吸收シテ完全二除去スルコトガ出來ルノデアル。唯茲二泩目ス べキハ異性副反應ガ閣羊以外二於イテ家鬼型及ビもるもつと型/如何 ズ反應ヨ現ハスコトデ，コノ點ョリ見ル時，異性沈降素ハソノ型式二於イラ 3.氏抗元ノ一般型式习亂サネバナラナイノデアッテ，又事實上種々異型，異性 抗元，存在スベキコトハ Fukuhara u, Ando(5) ，細菌性異性抗元二關スル事實 ヨリモ察知デキルノデアル.

翻ツテ Friedberger ハ,コノ異性沈降素 $\ni$ 類脂體ト見做シ，えーてろ浸出 $=$ ヨ

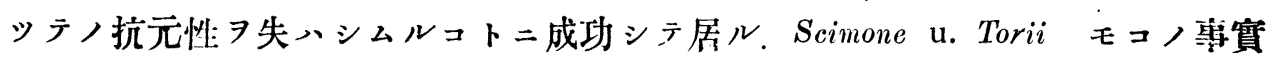
二證左ヨ與へテ居ルノデアル，更二又酒精浸出液习以テモ亦異性沈降素习確證 シタノデアル. (Sordelli u. Pico, Sachs u. Guth, Guth, Tuniguchi u. Taoka) 而シテ Collier u. Knoller 八異性反應 ヨ. Stärke-u. Massentiter，併用ニョッテ制 別スルコトガ出來ルト云ッテ居ル，即チ，前者ナル抗元稀釋ヨ以テスル檢查方 法ニョッテハ大シタ差異 $コ$ 見出セナイノ二反シテ,異性沈降反應入, Ma: sentiter 郎チ，抗血清稀釋檢查方法ニ於イテハ，著シク同種沈降反應二劣ルノデアル。

上述ニョッラ明ナャウ二，從來單二非特異性反應卜見做サレタ血清反應モふ 氏抗元，䦐明ト共二重大ナ意義ヨ持ッャウニナリ，ソノ一部八解决セラレタ，

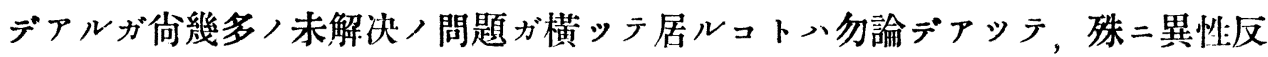
應ガ々.氏，概念ニョッテ，少今後如何ナル進步ヨナスべキカ，又異性反應，解 說二更二新シイ理論ガ生ルべキモノデハナカラウカ，而シラ所謂非特異性反應 トノ關係ボ如何樣二開拓セラレヤウナドハ今後最モ興味アル題材ニナルべキデ ハナカラウカ。 


\section{第 4 節 種屬特巽性ノ生物學的耊皘}

上述各節ニテ明ナヤウニ，血清學的特異性ノ概念二幾多/新事實ガ附加セラ レテ迁稌曲折ヨ重ホテ來タノデ, 從ッテ種屬特異性ノ生物學的意義モ少ナカラ

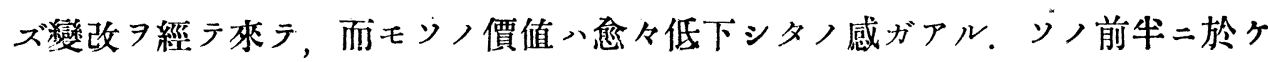
ル業績ハ，第 1 節二於ラ既二述心゙ラ置イタヤウ二，相當大規模ナ企モアリ，可 ナリ見ルベキモノガアッタノデアルガ，ソノ後先ッ゙第 2 節類族反應ノ除去ト併 行シラ特異性 ヨ明暸ナラシメヤウトノ方向ニソノ主力ガ注ガレ，引續イラ單二 鑑別 7 容易ナラシムル方法ノミガ講ゼラレテ，殊二血清反應ノ理論的考察ガ微 ニ入リ細ヨ第ッニッレラ特異性/根元 $习$ 化學的造構二置クヤウニナリ, 盆々雇 ミラレナクナッタ。而シテ本特異性八血清反應ノ理論的考察二於ケル一對照命 題或ハ單ナル供試材料卜見做ス二過ギナクナリ，ソノ本來ノ意義ハ失ハレッ、 アルノ觀ガアル。

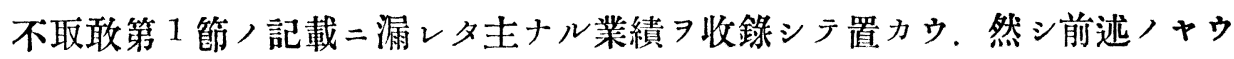
二第 2 節以下, 佮題ノ研究對照トシテ用ヒラレテ,ソノ序トシテ從來ノ事實 多少トモ進ンダ見地カラ追試シ得タト云フニ過ギナイモノガ多イ（第 2 節， 項過敏症二關スル項月 $习$ 參照ノコト).

\section{第 1 項 人・猿 $ノ$ 鑑 別}

本項八研究命題入，人·猿，鑑別カラ更二進ンデ人種間，差異，個性的變移 見出サウトスルニ及ンデ居ル. Weichardt ガ飽和吸收法二據ツテ人・猿間，相違 八云フニ及バズ，個性的差異 見出シ得タト云ッテ居ル。Bruck 八補體結合反 應习用七テ人・猿入勿論白晢, 眥古及ビまれー八人種間，辨別二成功シタト報シ テ居ル。然シ，カ、ル微細ナ鑑別二就イテハ之ルヨ否定スル人ガ少クナイ. (Linoissier u. Lemoine, Marschal u. Teague, Fitzgebald). 否ソレノミナラズ, 人・ 猿間ニ於イテモ少不可能トシタコトモアルノデアルガ (Biondi), ソノ檢查方法 及ビ免疫元, 加工 $=ヨ$ ヨ, 人・猿間, 鑑別, 出來得ルコトハ間違七ノナイ所デ

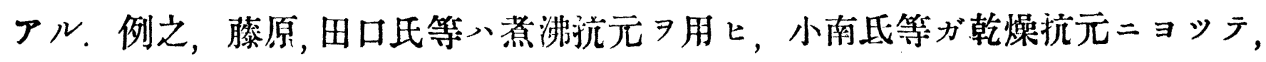
ソノ差ヨ著明ナラシメ, 且ッBruck ト等シク補體結合反應ヨ以テ, ソノ制別 ヨ容易ナラシメ (柴山, 藤原), 或又 Schwarzmann ガ受働性過敏症反應ニョッ 
丙藤達男述 (2537)

テソノ可能性ヨ認メテ居ル等デアル.

最近 Uhlenhuth 八永年ノ經驗 ニ遭遇フルモノデアルコトヨ゙指摘シテ居ルノハ既述ノ通リデアル.（第 2 節, 第 1 項參照).

然シ他方ニ於イテ; 近時同種血球凝集素ノ進展二伴ッテ, コレヨ規隼トシテ 本命題ガ一活路 7 見出シ得ルコトハ極メテ可能性ガアルノデアル. 此レニ就イ テハ項ヨ更メテ記述スルコトニスル.

\section{第 2 項同種血球凝集素}

先ヅ Landsteiner 等 $ニ ョ ッ ラ$ 同種血球凝集素ガ提唱セラレ, 人類學上或ハ法 醫學上等二新奇十倾域ガ開ケタノデアル，郎チ法醫學上ノ個州及ビ親子，鑑 別, 或又, 人類學上人類系數 7 以 テ人種別ニ一根據 $\ni$ 與へャウトスルガ如キ デアル．ソノ詳細ハ落ニ記述シ得ル所デナイ。（交硐トシテ有名ナルモノ八 Landsteiner, Dungern u. Hirschfeld, Berunstein, Furuhata \& Kishi, 特二本邦二於イテ 八宮路，中島，古畑，岸，二宮，最近二於ヶル吉村，高橋氏ノ業績等枚擧二遑 ガナイ). 又人種系數及ビ血液型二就イテノ概說及ビ理論的考察モ省クコトト シ, 本項二於イテ特二泩目 $习$ 促サムトスルハ,コノ血液 4 型 $习$ 免疫元トシテ更 二進ンダ境地ガ展開セラレテ居ルコトデアル.

Schiff 八, 4 型，人血球中第 2 型郎 A 凝集元 $习$ 有スル血球入免疫元性ガアッ テ，家兔二於イテ型特異的ノ凝集素 ニョル人種, 制別, 可能性 7 說キ, 且ッ又, 川羊血球二對スル溶血素 抗元中二ハふ氏抗元ニ一致スル類脂體ノアルコトラ䦕明シタノデアル．人型血 球，免疫元性／如何八, 既= Dungern u. Hirschfeld, Kirihara, Kolmer u. Trist, Hooker u. Anderson 等ニョッテ型特異性凝集素ノ出現ノ如何 7 甲論乙駁シテ居ッ タノデアルガ, 茲二至ッテ型特異州抗元ノ存在 確證スルニ至ッタノデアル.

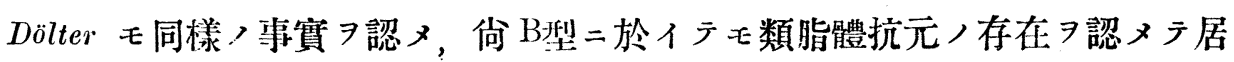
ル, Landsteiner u. Scheerモ酒精浸出物デ沈降ス心゙沈降素ヨ容易ニ得ラルトシテ 
居ル、此等ガふ氏抗元ト如何ナル關係ヨ持スルカハ論焭中ノコトデ, Hallier u. Hirzfeld ナド八，之レヨ否定シテ居ルガ，何レニシテモ血球中二型特異性抗 元ノ存在スルコトハ確カデアル.

最近本邦二於イテ大內氏八，血清，血球各成分，殊二，すとろーま等二於テ 總テ型特異性ノ抗元ガ存在スルコトヨ, 凝集補體結合反應等习以テラ確メタノ デアル．茲二於イテ人血球，血清等、人類トシテ種族特異性抗元ノ以外二型特 異ノ抗元ヨ有スルコトガ確メラレテ，人類學，生物學ノ見地カラシテモ一段， 進步ヨ來タシタノデアル。

而シテ同種血球凝集素八，登弱ナガラ人類以下ニモ各特異ノ型特異性トシテ 存在スルモノデ, 可ナリ廣ク行キ渡ッテ居ルノデ,必ズ將來アルぶキモノデアル

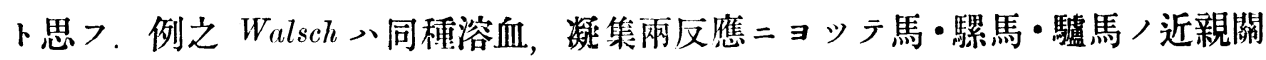
係 $\ni$ 明示シャウト試ミテ居ル，又 Landsteiner u. Scheer 等八同種血球凝集素カ ラ出發シテ近親關係习先疫血球凝集素 ノ種屬的關係，郎于種二特異ナル物質，異同及ビソノ遺傳等ヨ觀察シ，更二進 ンデ人・猿間二於イテ，先疫溶血素ヨ以テンノ微細ナル關係 血型ノ異同等 $习$ 檢查スルニ至ッテ居ル.

同種血球溶血素ハ人類二於イテホダ差程ノ意義ヨ有シテ居ラナイ.ソノ正常 特卜病的性狀二於イテノ異動モ少ナカラズ, 利用率ハ極メテ少ナイノデアルガ, 血球，溶血素二對スル渵抗等 $コ$ 見ル時ハ，凝集性血型ニ一致スト見做シ得ル モノガアル. (Blumenthal in Oppenh. Hb. II Aufl. II. Bd.) 且ッ血清中二八同種 溶血素二對スル型特異的阻止物質，存在师認メラレテ居ルノデ，(Moss, Gräfe u. Graham)，コノ方面モ亦檢查術式，改善卜共二何等力展開 ナイ.

何レニシテモ動物血液中二型特異性物質ノ存在スルノ八確ナコトデ，且ッソ レガ廣ク動物界ノ各種屬間二存在シテ各又種屬的特異性 ヨモ併有スルモノデア リ，之レ二更二異性抗元ガ點綴スルコトニョッテ，コノ方面八複維 ヨ加へルト 共ニ益々微細ナル鑑別へト展開セラレッ、アルノデアル. 
內

藤

達

男

述

(2539)

\section{第 3 項哺䄯類以下儿鑑別}

第 1 節記載ノモノ以後二ソ大シタ業績 $コ$ 見ナイ。殊二前述ノヤウ二理論的考 察, 副產物ト云フ二過ギナイモノガ多イ。

るるもと・家鬼 (Bordet)，羊對山羊 (Schur) / 鑑別二成功シナカッタトモ 記述セラレテ居ッタガ, 既述ノャウニ Hamburger 八山羊・羊・牛血液間 7 相互 ノ比較ニョリ，奥由氏八川羊・牛及ビまうす・らつて間习检查方法, 免疫操作，

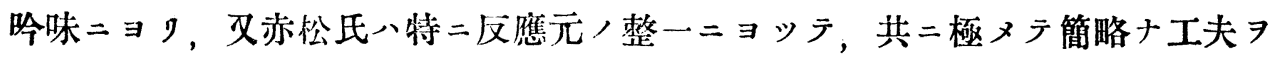
加へテ精密ナ成績ヨアダテ居ル. 又 Otto u. Cronheim, Schwarzmann ガ過敏症二 ヨッラらって・まうす間ノ漞近關係ヨ著明ナラシメテ居ルコトナドハ皆既二詳述 シテ居ル所デアル，又操，須賀氏等ガ生體丽吸收法习基礎ヅケタノ八，大ナル 收穫デアル．ソノ他，「熱あるから」又ハ「煮沸抗元」等ノエ夫ヨ凝シタモノト シデ、Beger，新井及ビ小西氏，堺氏，Mantenfel，Rosenberg ソノ他ノ業績 見出シ得ル．（前節第 1 項參照).

更二前項ノ同種凝集素ニョッテ盡キナイ展開 山羊二於イラ種屬的差異 7 見出少トトシ (Bialbsulknia), 又 Walsch, Landsteiner 等ノ業績ハ前項二摘記シテ置イタ所デアル。

丈主氏抗元，展開或、Friedlberyer ニョル暴性抗元ガ如何ナル開發 モノカ, 而シテソレニ伴ッテ生物學的見地カラノソレラノ解䜅ガ亦如何ナル新 事實 提供スルモノカナドト期待シテモ强チ無柏ノコトデナイト思フ.

而シテ之レラョ詳細二考照シテ本命題ョ系統立テルト云フコトガ，血清學， 應用方面トシテ生物學ト關聯シテ必須ノコト、思フ。要之，本命題、血清學的 研究態度,戀僄二伴ッテ等閉二附七ラレテ居ルノ觀ガアルノデ，從來ノ業績 精查スルト共二系統的二整理シ方見ル必要卜價值ガアルモノト思フ。

\section{第 5 節 總 括 的 若 察}

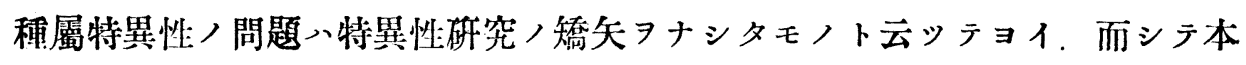
特異性二關聯シテ幾多ノ特異性ガ生ジタト同時二, 血清學, 總論的考察上二尠 ナカラヌ功績 積ムデ居ルコトハ特筆ニ價スル. 又血清學ノ觀點ガ漸次生化學 
ト密接シテ來ルニ從ッテ, 本特異性ノ本來ノ意義ニ少ナカラズ動搖习來シテ, 研究對象トシテモ貝弱ナモノトナッテ桃タコトハ既述ノ通リデアル。然シ理論 上ノ解說ノ都合ニョッテ特異性ノ意義二多少弶䔟ヨ來シタノハ己ム ガ，生物學的意義二於イテノ特異性ハソノ本來ノ意義 7 依然トシテ保有シテ居 ルコトハ動カナイト思フ。唯再三述ベタヤウ二研究對象トシテ難物デアルガタ メ，近特具劍二本問題 進展セシメヤウトノ企ガ少ナイバカリデアル，從ッ テ，ソノ業績モカ、ル推移ノタタ二蓝々總論的論究ノ傾向 7 取ッテソノ方面ノ 業績ノ積マル、ニ反シ，生物學的方面ノ實績ノ擧ガラナイコトハ己ム イ、總論的方面ノ業績トシテ特記ス心゙キモノ、各節ノ記述デ明デアルガ，ソノ 主要ナモナヨ摘錄シャウ.

1. 類族反應ノ除去ノ目的デアル华没血清ノ特異化法トシテハ, Weichardt 一飽和吸收法ガ未ダソノ䠛與 ヨ失ハナイガ, 最近本邦二於イテ生體內吸收法、 俊秀ナルガ傳へラレテ，コノ方面二一段ノ新生面ガ開ラカレタコトニナル，

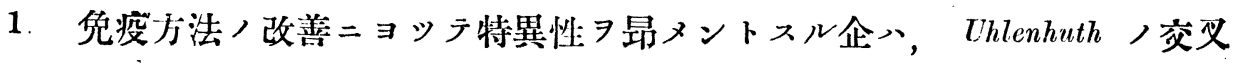

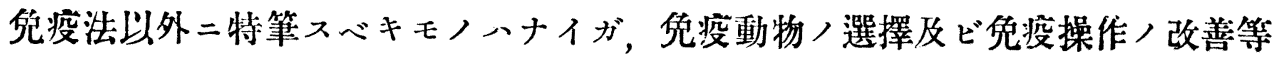
ニョッテ多少ノ進步ヨ觀テ居ル.

1. 又免疫元二對シ人工的操作 7 加ヘルコトニハ可ナリ檢觉ガ積マレタ. 但 シコノ方面ノ努力八生物學的見地ョリスル㭙、多少深入リシ過ギテ居ルノデ， ソレガ法醫學, 衛生學上ノ蛋白ノ鑑別ニ大ナル意義ノアッタニ比シテ，ソノ効 果ハ少ナイノデアル.

1. 檢香方法ノ進步八他二比シテ塞ロ少ナイト云ハネバナラヌ。近㭙 Friedberger 一派ガ非特異性抗元，政索二伴ツテ沈降反應ノ効價ノ制定上二種々ノ新 事實 $习$ 提供シタノ八特二泩目二價ス。

1. 更二進ンデ異性反應ノ攻栄ガ進步シテ理論的方面ニ少ナカラヌ新知見 加へッ、アリ，コノ方面ノ解明ニ伴ッテ類族反應ソレ自體ノ研究ニモ何等カ新 生面ガ開ラカルべモノデハナカラウカトハ余ノ特ニ期待スル所デアル. 
次ギ二生物學的意義二於イテノ所﨎トシテハ上述ノヤウニ摘記スべキモノ八 殆ンド見當ラナイ，唯余入同種血球凝集素等ノ如キ矿索二伴ッテコノ方面二新 生面ガ展開セラル、ヨ期待シテ居ルモノデアル.

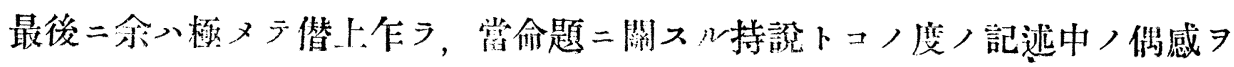

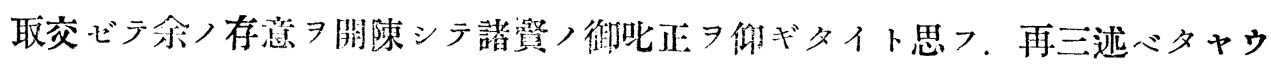
二, 余一, 血清學/理論上ノ推移、别トシテ, 生物學的意羕二於イテノ種屬特異 性ガ嚴存ス心゙キコトヨ主張シテ居ルノデアルガ, ソノ存意八詮ズル二, 血清學 ，研觉成績 以テ生物學上，知見二解說 試ミルノガ，種屬特晎性ノ本來ノ月 的デアッテ，カ、ル研究的態度,今日少意義アルコトク指摘シタイノデアル. 多ク八人ノ內 $=$, 血清學ノ進步、特異性問題 7 化學的二解釋スルャウニナリ, 從ッテ生物學トノ關聯ハ失ハレテ，ソノ意義ハ血清學上愈々䫎小トナッテ來タ トシテ居ル，實際ニ於イラ今日，血清學ノ進展ガ愈生物學的見地カラ遠ザカリ ッ、アルノハ否マレナイシ, 又カ、ル傾向ニョッテ血清學ガ進步ス心゙キモノデ アルコトモ淮シモ首肯シナイモノハナイ、然シ，余ハカ、ル血清學ノ趨勢ダカ ラ生物學的意義ノ特異性が血清學上ソノ根據习失ヒッッアルトハ云ヒタクナ イ、唯理論的論究上ノ對象トシテノ價值ノ减少、否マレナイノデ，又ソノ取材 トシテノ範圍二狹少タ來シテ居ルノモ己ムヨ得ナイガ, 本特異性自體ハソノ本 爽ノ使命ヨ有シタマ、依然トシテ動カナイモノデアルト若へタイノデアル．即 チ，血清學的特異性ノ研究 生物學的見地カラ解釋シャウ, 或ハ云七換へレバ 血清學的所見 以テ生物學的知見ニ加へャゥトノ努力ノ意義アルコトヨ主張ス ルモノデアッ，尙之レョ云ヒ換レバ，近特生物學的意義 7 嚴存セル取材ニョッ テノ血清學的知見ガ貧少デアリ，ンノ方面ノ努力ガ战視セラレ勝テナノタ遺揻 トシタノデアル.

㖉ッテ双余ノ考二引續キ思ヒ浮ンデ桃ルノハ類族反應二對スル研究的態度二 就テデアル，從來、特晎性ヨ著明ナラシムルニ專ラデアッテ特異化法二進步 桃タシタノデアルガ，他方類族反應自體，血清學的或、生化學的研究又ハンノ 
生物學的意義ニ就イテノ考察等ニ缺クル所ガナカッタデアラウカ. 勿論此等， 事項入現在迄二於イテハ寧口机上ノ空論ト一笑セラル、嫌ナシトスルモ, 現在 二於イテ既二異性抗元，特二ふ氏抗元，理論的考察二件ッテ非特異性反應二一 光明ガ與へラレ，又同種血球癡集素ガ意外ニソ，展開ヨ進メテ居ル所カラスル ト强無嵇ノコト、モ云へナイト思フ。

要八種屬特異性ノ研究ガ現在ノ趨勢二壓セラレテ，ソノ本來ノ意義ノ存在ガ 膤視セラレテ居ルノヨ指摘シテ, 種屬特異性ハ之レヨ嚴然生物學的見地ヨリ観 ル特, 特ニ意義アルモノデアルコトヨ主張シタイノデアル.コノ點ニ就イテハ 倘後編二於イテ再度考察シテ見タイトノ豫定ホノデ特ニ諸彥ノ御敎示 デアル．（17/X 1928脫稿.）（本編未完.） 